\title{
FEA study for the mechanical strength evaluation of self-adhesive cements used for the restoration of integral ceramic inlays
}

\author{
Studiu FEA pentru evaluarea rezistenţei mecanice a cimenturilor autoadezive \\ utilizate pentru restaurarea inlay-urilor integral ceramice
}

\author{
Ana Maria Buruiană', Cornelia Bîcleşanu', Iulian Vasile Antoniac², Dan Ioan Stoia ${ }^{3}$, \\ Anamaria Florescu ${ }^{1}$ \\ ${ }^{1}$ Facultatea de Medicină Dentară, Universitatea „Titu Maiorescu“, Bucureşti \\ Universitatea Politehnică, Bucureşti \\ 3Universitatea Politehnică, Timişoara
}

\begin{abstract}
REZUMAT
Scop. Scopul acestui studiu este de a studia rezistenţa adeziunii inlay-ului integral ceramic (IPS max PressIvoclar), în 3 situaţii clinice diferite, comparând în acelaşi timp şi performanţele clinice a două materiale de cimentare diferite, şi anume Variolink Esthetic DC - Ivoclar şi Maxcem Elite - Kerr.

Material şi metodă. Procesarea imaginilor dentare s-a realizat cu ajutorul software-ului Mimics 10, în care a fost importată colecţia de imagini DICOM rezultate la scanarea CT. Scopul procesării a fost acela de a transforma colecţia de imagini 2D într-un volum care să reprezinte structura unui molar integru. După reconstrucţie, utilizând programul de modelare CAD SolidWorks 2013, s-au realizat operaţiile geometrice specifice obţinerii celor 3 tipuri de inlay-uri. Au rezultat modelele pe baza cărora s-au generat cele 3 ansamble. S-au ales 3 direcţii de solicitare care, pentru consistenţa rezultatelor, s-au păstrat pentru toate cele 3 inlay-uri. Direcția $(\Delta 1)$ simulează o tracţiune normală pe inlay, direcţia $(\Delta 3)$ simulează o solicitare de forfecare, iar direcţia $(\Delta 2)$ o solicitare oblică, combinată. Modulele forţelor de solicitare au fost de 90 respectiv $230 \mathrm{~N}$ şi s-au aplicat pe rând fiecărei direcţii de solicitare. Analiza cu element finit s-a realizat cu software-ul FEA Ansys 13. Modelele geometrice provin din SolidWorks 2013, unde au fost asamblate şi exportate apoi în format compatibil Ansys. Rezultate. Ambele tipuri de ciment prezintă valori de rezistenţă mai ridicate decât valorile de tensiune înregistrate atât la nivelul suprafeţei, cât şi la interfaţă. Acest lucru ne indică faptul că oricare dintre cele două valori de solicitare, aplicate după oricare dintre cele 3 direcţii, nu va produce ruptura niciunuia dintre cele două tipuri de materiale de cimentare. Din cauza apariţiei tensiunilor de forfecare, în cazul inlay-ului iC, solicitarea orizontală depăşeşte valoarea rezistenței mecanice a materialului de cimentare pentru solicitarea accidentală de $230 \mathrm{~N}$, dar nici în acest caz nu se va produce ruptura.

Concluzii. Variolink II are proprietăţi de adeziune superioare cimentului Maxcem, motiv pentru care, indiferent de configuraţia geometrică, direcţia forţei de aplicare şi modulul utilizate în simulare, adeziunea realizată de cimentul Variolink are rezistenţa mecanică mai ridicată.
\end{abstract}

Cuvinte cheie: inlay integral ceramic, Variolink Esthetic DC - Ivoclar şi Maxcem Elite - Kerr, element finit

\begin{abstract}
Aim. The purpose of this study is to evaluate the strength of the adhesion of ceramic inlays (IPS max Press-Ivoclar) in 3 different clinical situations, while comparing the clinical performance of two different luting materials (Variolink Esthetic DC - Ivoclar and Maxcem Elite - Kerr).

Materials and methods. The image processing was done using the Mimics 10 software. The purpose of the processing was to transform the $2 \mathrm{D}$ image collection into a volume representing the structure of a molar. After the reconstruction, using the SolidWorks 2013 CAD modeling program, geometric operations were performed to obtain three types of inlays.

Three directions of stress have been chosen and they have been preserved for all 3 situations: the direction $(\Delta 1)$ simulates a normal traction on the inlay, the direction $(\Delta 3)$ simulates a shear stress, and the direction $(\Delta 2)$ a combined oblique stress. The load forces modules were 90 and $230 \mathrm{~N}$. Finite element analysis was performed with FEA Ansys 13 software.
\end{abstract}


Results. Both types of luting cements have higher resistance values than the values recorded at both the surface and the interface. This indicates that either of the two application rates applied in any of the three directions will not damage any of the two types of luting materials. Due to the occurrence of shear stresses, in the case of iC inlay, the horizontal stress exceeds the value of the mechanical strength of cement for the accidental stress of $230 \mathrm{~N}$, but neither in this case there will be no damage.

Conclusion. Variolink II has better adhesion properties than Maxcem cement, which is why, regardless of the geometric configuration, the direction of the application force and the modulus used in the simulation, the adhesion of Variolink has higher mechanical strength.

Keywords: all integral ceramic inlays, Variolink Esthetic DC - Ivoclar şi Maxcem Elite - Kerr, element finite method

\section{INTRODUCERE}

Fixarea unui inlay utilizând cimenturile dentare convenţionale implică un protocol destul de elaborat în ceea ce priveşte atât tratarea ţesuturilor dentare dure (demineralizarea acestora), cât şi condiţionarea suprafeţei ceramicii utilizate. Din dorinţa de a simplifica acest protocol, au apărut cimenturile dentare autoadezive, care au încorporat în compoziţia chimică agentul de adeziune (1-3).

\section{MATERIAL ŞI METODĂ}

\section{Reconstrucția şi modelarea geometrică}

Procesarea imaginilor dentare s-a realizat $\mathrm{cu}$ ajutorul software-ului Mimics 10, în care a fost importată colecţia de imagini DICOM rezultate la scanarea CT. Scopul procesării a fost acela de a transforma colecţia de imagini 2D într-un volum care să reprezinte structura unui molar integru.
Analiza cu element finit s-a realizat cu software-ul FEA Ansys 13. Modelele geometrice provin din SolidWorks 2013, unde au fost asamblate şi exportate apoi în format compatibil Ansys.

Fixarea molarului s-a realizat prin definirea suprafeţelor din zona rădăcinii ca fiind fixe. Solicitarea s-a aplicat pe întreaga suprafaţă exterioară pentru fiecare dintre inlay-uri pentru a evita apariţia tensiunilor punctiforme la acest nivel. Direcţiile de aplicare ale forţelor au fost cele definite anterior, iar în figura 1.b) se poate observa încărcarea verticală a inlay-ului iA.

Datorită faptului că simularea numerică se va realiza în domeniul liniar elastic al materialului, proprietăţile mecanice necesare unei astfel de simulări sunt modulul lui Young şi coeficientul lui Poisson, parametri care s-au extras din literatura de specialitate.

Analiza cu element finit s-a realizat în scopul de a stabili starea de tensiune şi deformaţie din toate

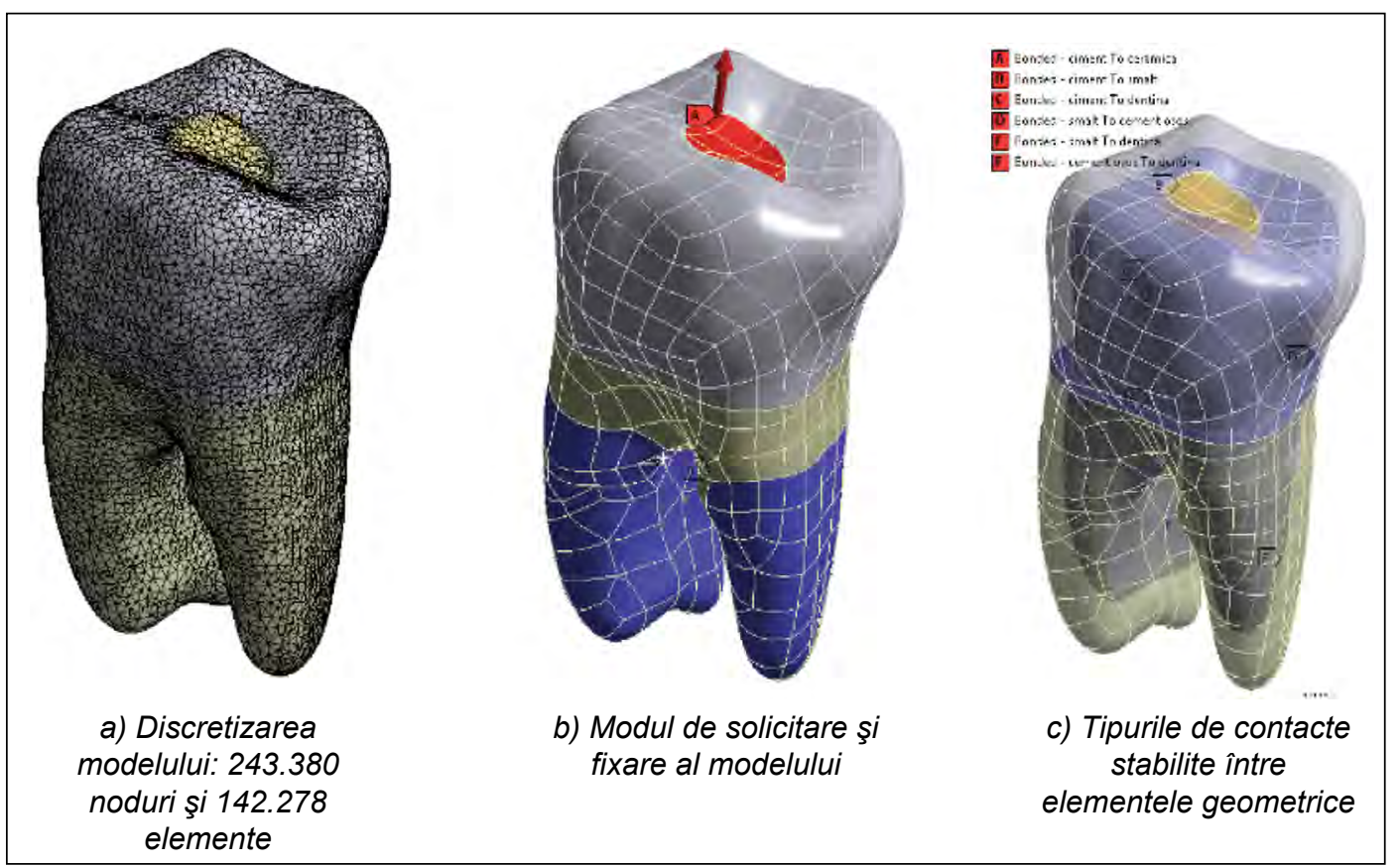

FIGURA 1. Parametrii de intrare ai analizei cu element finit 


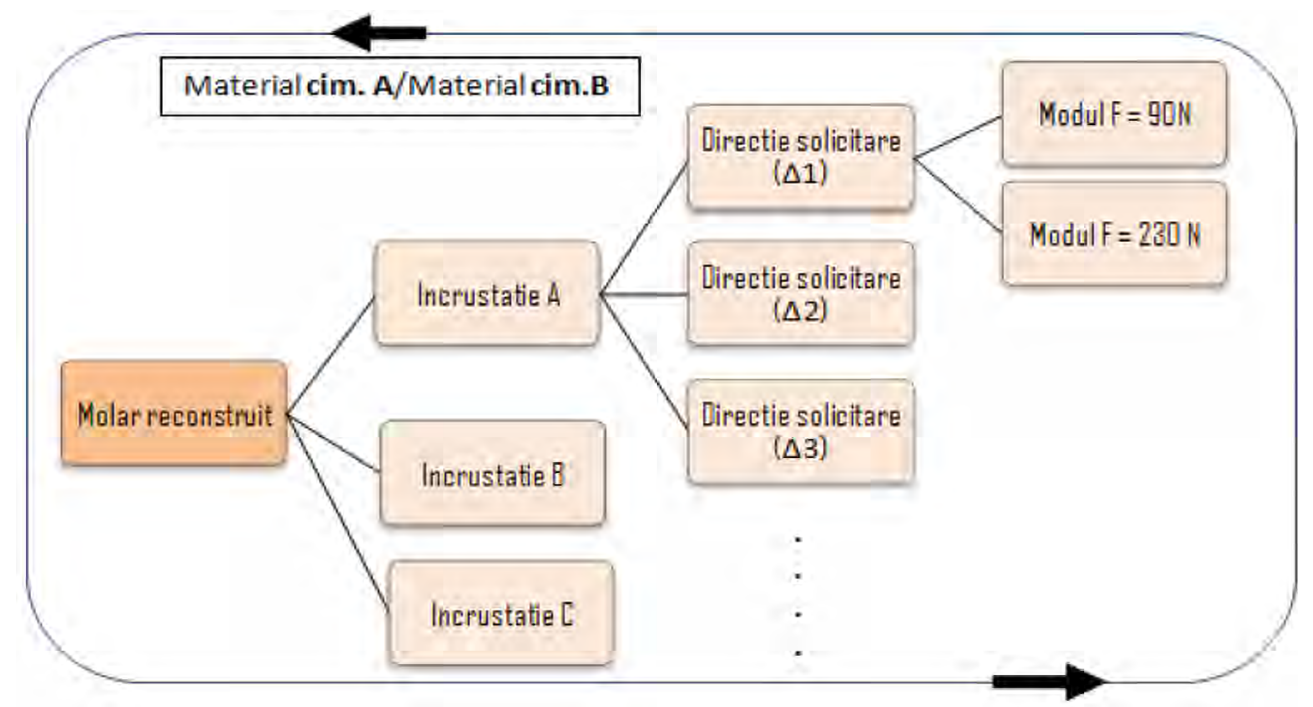

FIGURA 2. Structura analizei cu element finit

elementele geometrice ale ansamblului molar-inlay. Situaţiile simulate s-au generat din 4 variabile:

- 2 variabile de material: Variolink şi Maxcem;

- 3 variabile geometrice: cele 3 geometrii (iA, $\mathrm{iB}, \mathrm{iC}$ ) ale inlay-urilor;

- 3 variabile tip direcţie: direcţia verticală, orizontală şi oblică a forţei de încărcare;

- 2 variabile tip modul: valoarea forţei de încărcare.

Tensiunile urmărite cu precădere în simulare au fost cele de la interfaţa materialului de cimentare inlay, dar şi de la nivelul ţesutului dentar, pentru a observa modificările bruşte ale tensiunilor în zonele limită ale materialelor.

În vederea realizării graficelor de variaţie a tensiunilor atât la interfaţă, cât şi la suprafaţă, s-au stabilit două serii de puncte de control ale tensiunilor, puncte indicate în secţiunile din figura 3 , pentru cazul inlay-ului iA.

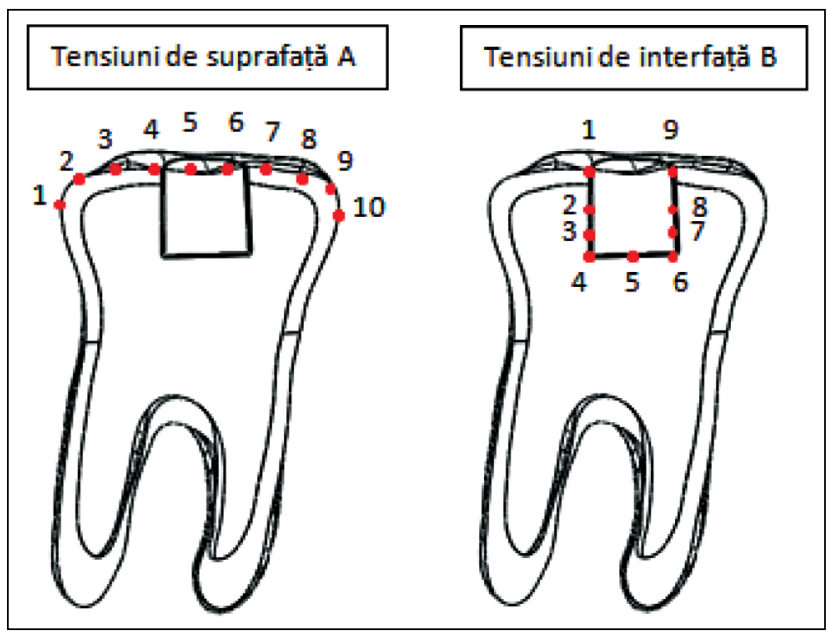

FIGURA 3. Punctele de control ale tensiunilor din suprafață $A$, respectiv interfață $B$

\section{REZULTATE ŞI DISCUȚII}

\section{Rezultatele modelului de inlay iA (ocluzal)}

Rezultatele simulărilor numerice ale modelului de inlay iA sunt prezentate în figura 4, corespunzătoare direcţiilor de încărcare exterioară verticală. În fiecare dintre acestea se prezintă hărţile de culoare care indică distribuţia tensiunilor la nivelul componentelor ansamblului. Zonele de gri şi culoare albastră reprezintă zone foarte puţin solicitate, iar zonele reprezentate în culori calde sunt zone intens solicitate. Prezentarea grafică s-a realizat sub forma de secţiune longitudinală pentru a putea observa şi starea de tensiune şi deformaţie din interiorul volumelor. Toate hărţile colorate din figurile următoare s-au prezentat pentru valoarea de încărcare de 230 N, însă ridicarea graficelor de variaţie s-a realizat şi pentru valoare de $90 \mathrm{~N}$.

Deoarece, în fiecare dintre cele 3 situaţii ale direcţiilor de încărcare, punctul de aplicare a forţei a fost pe suprafaţa exterioară a inlay-ului, zonele cele mai tensionate ale suprafeţei dentare au fost la nivelul piesei protetice.

În cazul în care forţa are o direcţie simetrică faţă de inlay, tensiunile se distribuie uniform, circumferenţial, pornind de la valori mai mari în centrul suprafeţei exterioare şi ajungând la valori reduse în zonele marginale (fig. 4).

Tensiunile la interfaţa ciment-ţesut dentar sunt mai reduse decât tensiunile de suprafaţă, datorită modulului de elasticitate mai redus al materialului de cimentare.

Din punctul de vedere al valorilor de tensiune, ele se situează sub rezistenţa mecanică a ambelor 


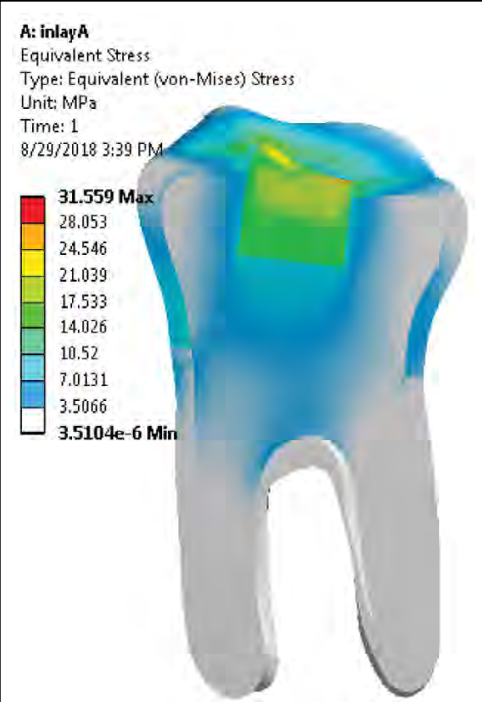

a. Tensiuni în secțiunea molarului

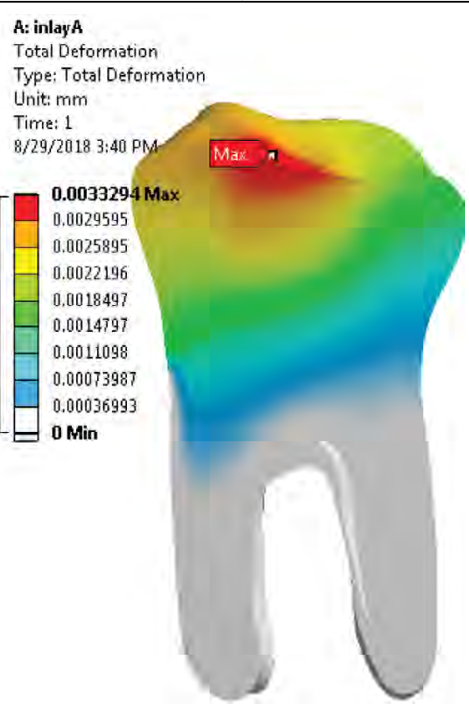

b. Deplasări în secțiunea molarului

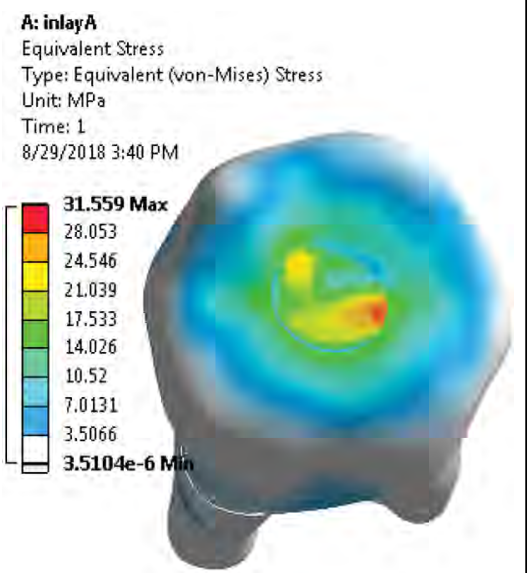

c. Tensiuni de suprafață - vedere caudală

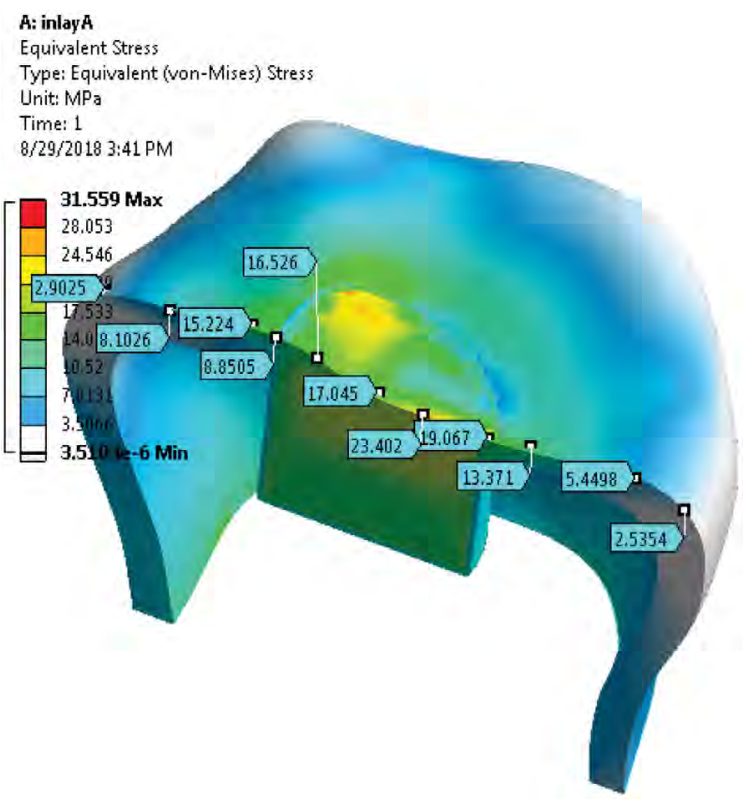

d. Harta tensiunilor de suprafață

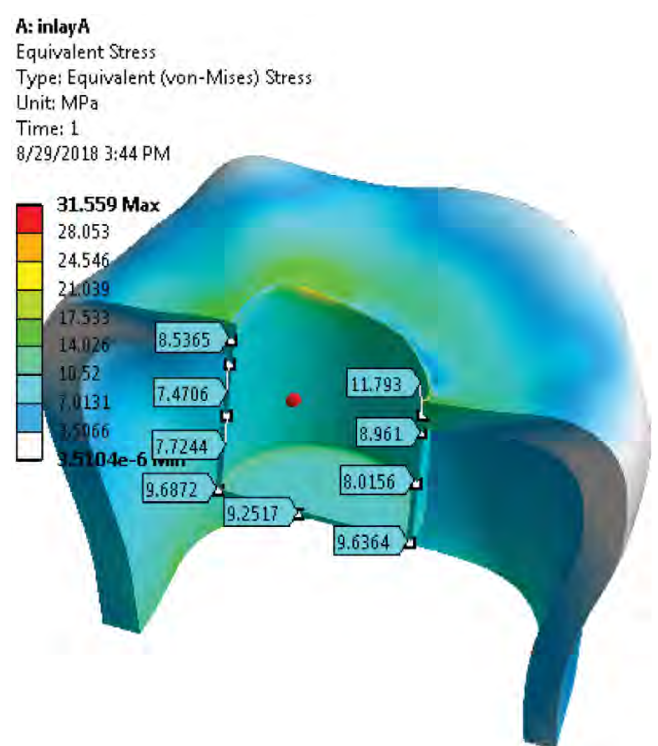

e. Harta tensiunilor de interfață

FIGURA 4. Rezultatele simulării pentru solicitarea verticală, $230 \mathrm{~N}$

tipuri de cimenturi adezive utilizate (Variolink şi Maxcem) şi mult sub rezistenţa mecanică a ţesuturilor dentare. Valorile de tensiune înregistrate în punctele de control se prezintă în tabelele 1 şi 2 , pentru fiecare valoare a forţei de încărcare. Tot aici s-au calculat mediile şi deviaţiile standard ale valorilor de tensiune pentru fiecare situaţiei de încărcare. Abaterile mari în unele situaţii se datorează faptului că nu întotdeauna punctul de control ales a coincis cu un element finit al reţelei de discreticare. În situaţia de lipsă a suprapunerii acestora, s-a ales un element finit învecinat.

În figurile 5-7 sunt reprezentate variaţiile de tensiune în conformitate cu punctele de control. Aces- tea s-au trasat pentru ambele solicitări ( 90 , respectiv $230 \mathrm{~N}$ ). Tot aici sunt reprezentate cu linie întreruptă, respectiv linie punctată, cele două seturi de valori ale rezistenţei mecanice ale celor două materiale de cimentare, la valorile prezentate în literatură (4-12).

Ambele tipuri de cimenturi prezintă valori de rezistenţă mai ridicate decât valorile de tensiune înregistrate atât la nivelul suprafeței, cât şi la interfaţă. Acest lucru ne indică faptul că oricare dintre cele două valori de solicitare, aplicate după direcţia verticală, nu va produce ruptura niciunuia dintre cele două tipuri de adeziv (fig. 5). 
TABELUL 1. Valorile de tensiune din suprafață

\begin{tabular}{|c|c|c|c|c|c|c|c|c|c|c|}
\hline \multirow{2}{*}{$\begin{array}{c}\text { Pct. } \\
\text { Ctrl. }\end{array}$} & $\mathbf{9 0}$ & $\mathbf{2 3 0}$ & $\mathbf{9 0}$ & $\mathbf{2 3 0}$ & $\mathbf{9 0}$ & $\mathbf{2 3 0}$ & $\begin{array}{c}\text { Media } \\
\text { (N) } \\
\text { mod=90 }\end{array}$ & $\begin{array}{c}\text { Std. (N) } \\
\text { mod=90 }\end{array}$ & $\begin{array}{c}\text { Media } \\
\text { (N) } \\
\text { mod=230 }\end{array}$ & $\begin{array}{c}\text { Std. (N) } \\
\text { mod=230 }\end{array}$ \\
\hline 1 & 0,42 & 2,90 & 0,94 & 4,1 & 3,5 & 8,41 & 1,62 & 1,65 & 5,14 & 2,90 \\
\hline 2 & 2,18 & 8,10 & 0,51 & 1,45 & 3,88 & 10,1 & 2,19 & 1,69 & 6,55 & 4,53 \\
\hline 3 & 5,63 & 15,24 & 3,87 & 12,75 & 6,52 & 24,35 & 5,34 & 1,35 & 17,45 & 6,11 \\
\hline 4 & 3,53 & 8,85 & 10,15 & 31,51 & 11,99 & 37,68 & 8,56 & 4,45 & 26,01 & 15,18 \\
\hline 5 & 6,65 & 16,52 & 4,24 & 14,23 & 16,07 & 36,98 & 8,99 & 6,25 & 22,58 & 12,53 \\
\hline 6 & 7,56 & 17,05 & 8,24 & 24,4 & 15,85 & 40,01 & 10,55 & 4,60 & 27,15 & 11,73 \\
\hline 7 & 9,69 & 23,4 & 11,57 & 32,59 & 19,39 & 41,61 & 13,55 & 5,14 & 32,53 & 9,11 \\
\hline 8 & 8,15 & 19,00 & 8,4 & 25,3 & 12,35 & 44,69 & 9,63 & 2,36 & 29,66 & 13,39 \\
\hline 9 & 5,75 & 13,37 & 6,45 & 18,5 & 9,12 & 23,16 & 7,11 & 1,78 & 18,34 & 4,90 \\
\hline 10 & 2,04 & 5,44 & 3,69 & 10,12 & 3,32 & 8,6 & 3,02 & 0,87 & 8,05 & 2,39 \\
\hline 11 & 0,62 & 2,53 & 2,54 & 7,24 & 3,04 & 8,15 & 2,07 & 1,28 & 5,97 & 3,02 \\
\hline
\end{tabular}

TABELUL 2. Valorile de tensiune la interfață

\begin{tabular}{|c|c|c|c|c|c|c|c|c|c|c|}
\hline \multirow{2}{*}{$\begin{array}{c}\text { Pct. } \\
\text { Ctrl. }\end{array}$} & $\mathbf{9 0}$ & $\mathbf{2 3 0}$ & $\mathbf{9 0}$ & $\mathbf{2 3 0}$ & $\mathbf{9 0}$ & $\mathbf{2 3 0}$ & $\begin{array}{c}\text { Media } \\
\text { (N) } \\
\text { mod=90 }\end{array}$ & $\begin{array}{c}\text { Std. (N) } \\
\text { mod=90 }\end{array}$ & $\begin{array}{c}\text { Media } \\
\text { (N) } \\
\text { mod=230 }\end{array}$ & $\begin{array}{c}\text { Std. (N) } \\
\text { mod=230 }\end{array}$ \\
\hline 1 & 3,32 & 8,53 & 7,25 & 21,37 & 8,34 & 30,29 & 6,30 & 2,64 & 20,06 & 10,94 \\
\hline 2 & 3,09 & 7,47 & 4,91 & 12,16 & 4,79 & 12,38 & 4,26 & 1,02 & 10,67 & 2,77 \\
\hline 3 & 3,05 & 7,72 & 4,43 & 11,56 & 3,67 & 9,15 & 3,72 & 0,69 & 9,48 & 1,94 \\
\hline 4 & 3,96 & 9,68 & 5,62 & 15,33 & 4,90 & 12,28 & 4,83 & 0,83 & 12,43 & 2,83 \\
\hline 5 & 3,61 & 9,25 & 3,90 & 9,77 & 3,30 & 8,30 & 3,60 & 0,30 & 9,11 & 0,75 \\
\hline 6 & 3,89 & 9,63 & 2,15 & 5,55 & 5,84 & 14,86 & 3,96 & 1,85 & 10,01 & 4,67 \\
\hline 7 & 3,20 & 8,01 & 1,15 & 3,10 & 4,49 & 10,98 & 2,95 & 1,68 & 7,36 & 3,98 \\
\hline 8 & 3,51 & 8,96 & 1,41 & 3,71 & 5,25 & 13,92 & 3,39 & 1,92 & 8,86 & 5,11 \\
\hline 9 & 4,45 & 11,79 & 4,82 & 13,81 & 13,57 & 35,99 & 7,61 & 5,16 & 20,53 & 13,43 \\
\hline
\end{tabular}

Pe de altă parte, atunci când direcţia forţei se modifică în sensul orizontalizării ei, modul de distribuţie al tensiunilor se schimbă. În figurile 6 şi 7 se pot observa atât valori de tensiune care punctual depăşesc valorile de rezistenţă ale materialelor de cimentare, dar şi un mod de distribuţie diferit. Acest lucru se datorează nesimetriei solicitării în raport cu geometria molarului. Se observă că depăşiri ale limitelor de rezistenţă mecanică se înregistrează doar în cazul în care solicitarea are o valoare de natură accidentală $(230 \mathrm{~N})$, nu şi în cazul încărcării fiziologice rezultate din procesul mecanic de masticaţie.

\section{Rezultatele modelului de inlay $i B$ (mezio-ocluzo-distal)}

În cazul celui de-al doilea inlay, simulările au decurs în aceleaşi condiţii şi cu aceleaşi proprietăţi ale materialelor ca şi în primul caz. Pentru consistenţa rezultatelor, hărţile de culoare au fost prezentate în acelaşi mod şi, de asemenea, şi secţiunile de reprezentare, respectiv vederile de sus ale molarului.

Datorită faptului că modelul de inlay iB este de dimensiuni mai mari decât modelul iA, este de aşteptat ca tensiunile care apar în materialul de cimentare, respectiv la interfaţa cu ţesutul biologic, să fie mai reduse ca valoare. Modul lor de distribuţie va depinde şi de această dată de simetria geometriei, respectiv de simetria direcţiei de încărcare faţă de geometrie.

În figurile 8-10 s-au prezentat rezultatele simulării după cele 3 direcţii de solicitare. Se poate observa că, la solicitarea verticală, din condiţii de simetrie, distribuţia tensiunilor este una relativ uniformă, pe când la direcţia oblică molarul se 


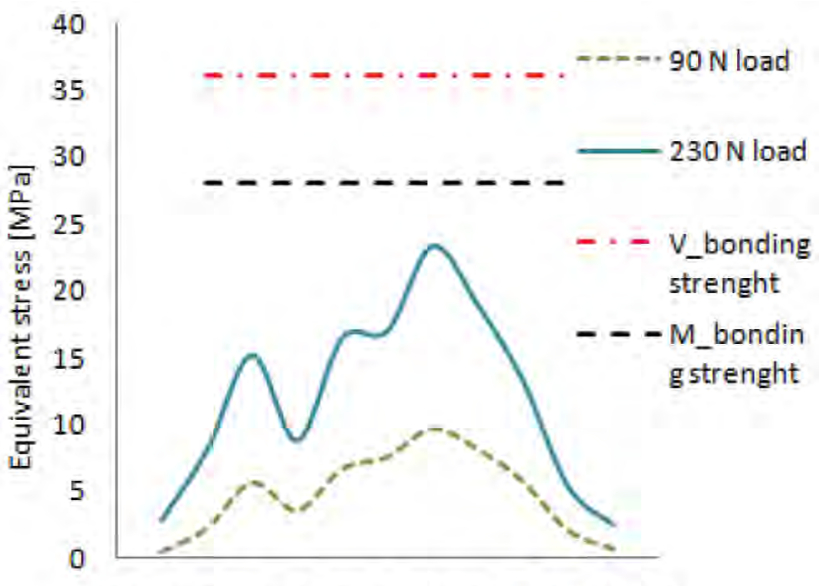

$\begin{array}{llllllllllllll}0 & 1 & 2 & 3 & 4 & 5 & 6 & 7 & 8 & 9 & 10 & 11 & 12\end{array}$

Node

a. Suprafață

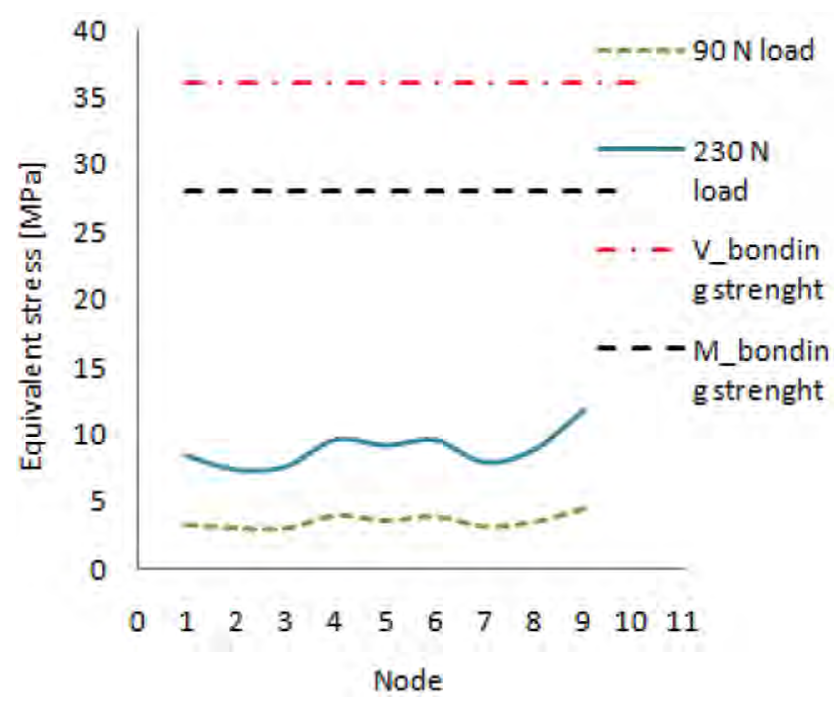

b. Interfață

FIGURA 5. Variația tensiunilor din suprafață a) şi interfață b) pentru solicitarea verticală

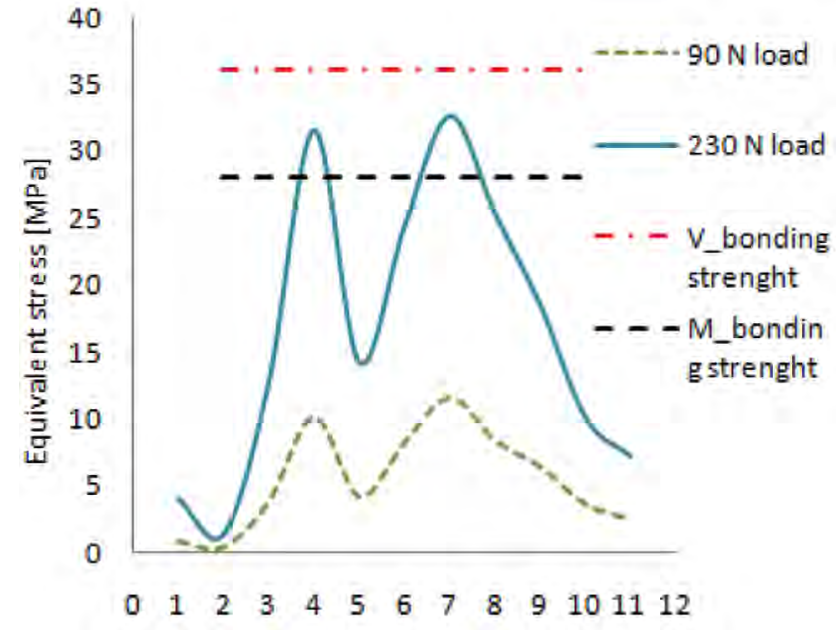

Node

a. Suprafață

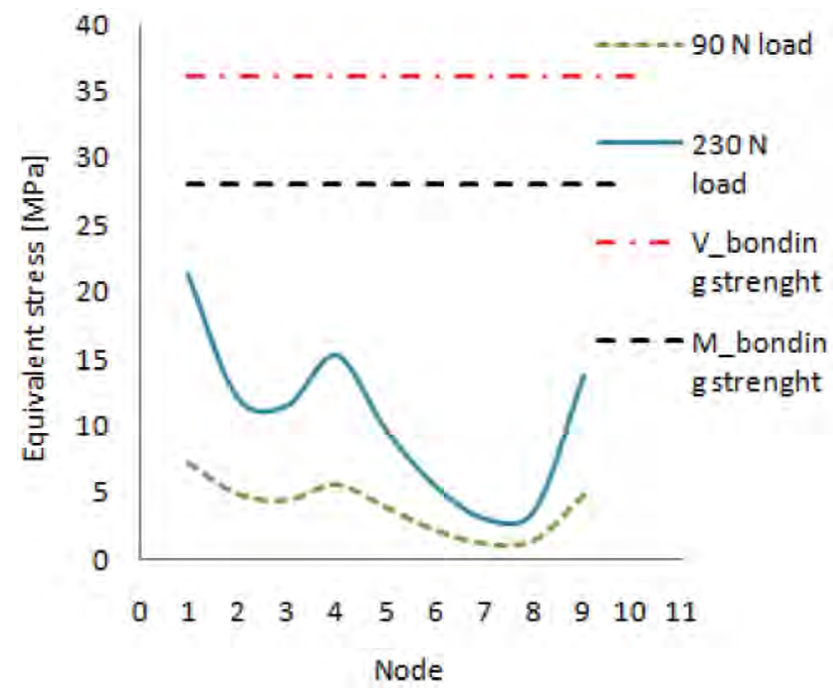

b. Interfață

FIGURA 6. Variația tensiunilor din suprafață a) şi interfață b) pentru solicitarea oblică

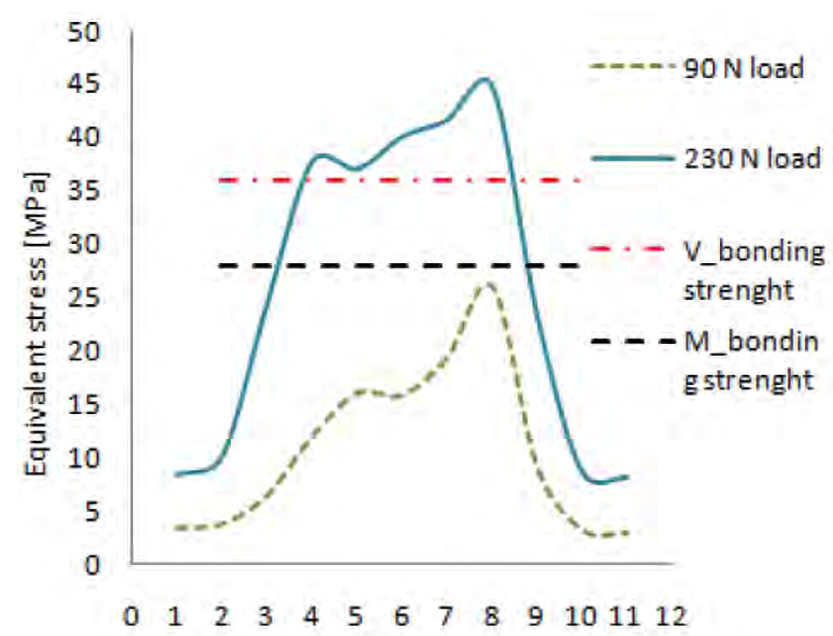

Node

a. Suprafată

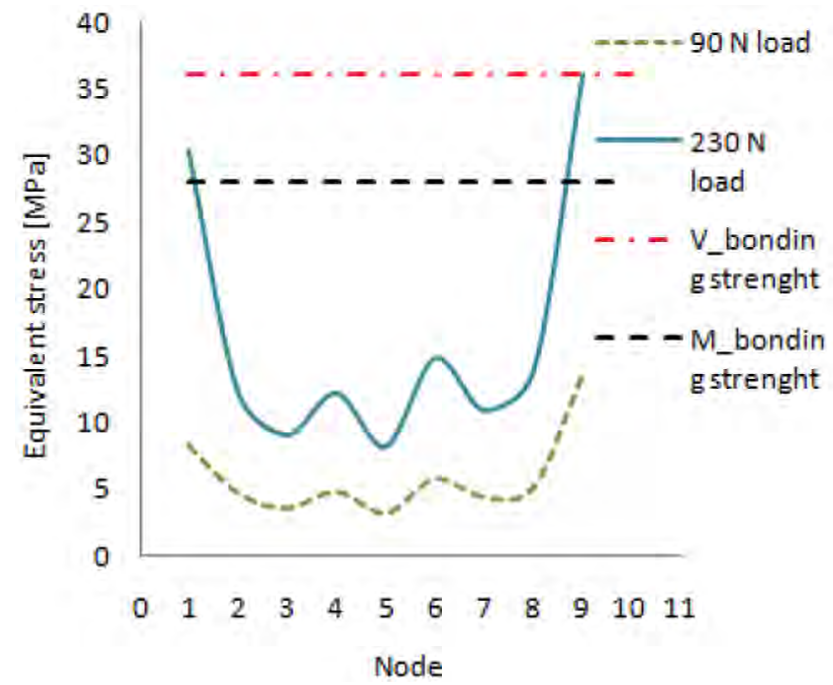

b. Interfață

FIGURA 7. Variația tensiunilor din suprafață a) şi interfață b) pentru solicitarea orizontală 
încarcă nesimetric, ceea ce duce la o distribuţie nesimetrică de tensiuni. La suprafața molarului (fig. 8.b) nu se pot observa liniile de trecere între diferitele materiale utilizate, ci trecerea se face relativ uniform. Spre deosebire de această situaţie, în cazul solicitării care simulează o forță orizontală (de forfecare), se constată o modificare bruscă a valorilor de tensiune de la materialul de restaurare (cel mai tensionat) la smalţul dentar, respectiv dentină.

În nicio situaţie simulată valorile de tensiune nu depăşesc valorile rezistenţei la rupere a materialelor adezive, lucru generat în mare măsură de forma şi dimensiunile acestui inlay.
În cazul în care încărcarea nu s-ar mai face uniform pe suprafaţa inlay-ului, modul de distribuţie ar fi diferit şi la nivelul interfeţei.

Un rol foarte important important în simulare îl joacă şi gradul de implantare a molarului, adică suprafaţa totală a osului alveolar care se găseşte în jurul acestuia. Simulările au considerat o implantare totală şi completă, pe toată suprafaţa radiculară, acest lucru contribuind la rigiditatea modelului şi, deci, la apariţia unor tensiuni mai mari. În realitate, datorită elasticităţii ţesuturilor înconjurătoare ale dintelui, valorile de deplasare totală a molarului vor fi mai mari, iar tensiunile din acesta mai reduse.

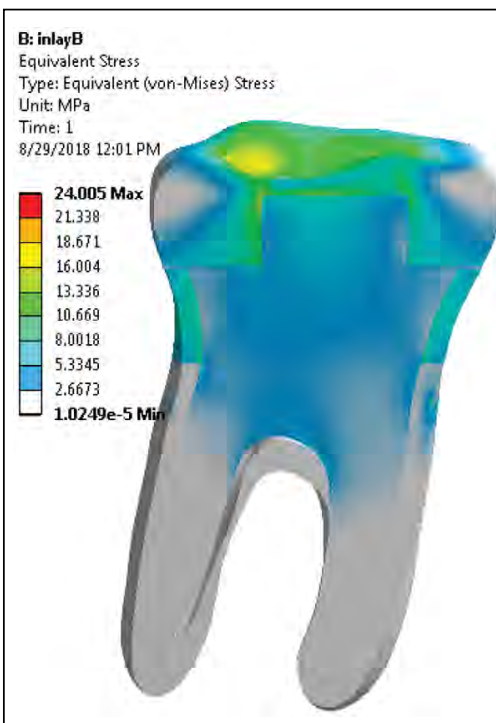

a) tensiuni în secțiunea molarului

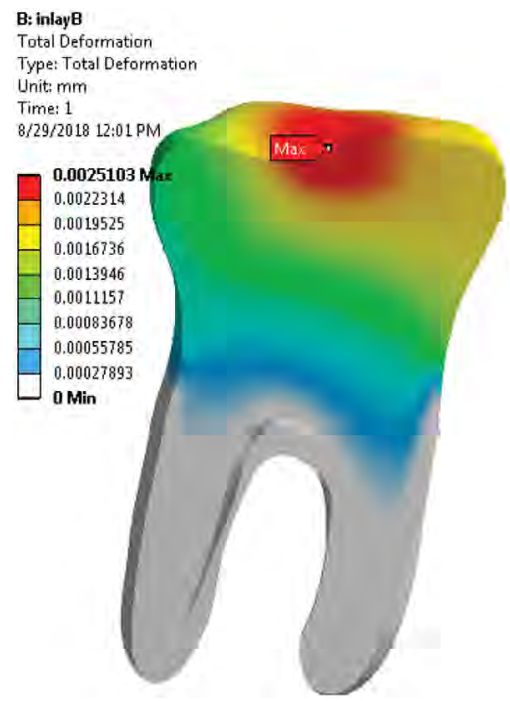

b) deplasări în secțiunea molarului

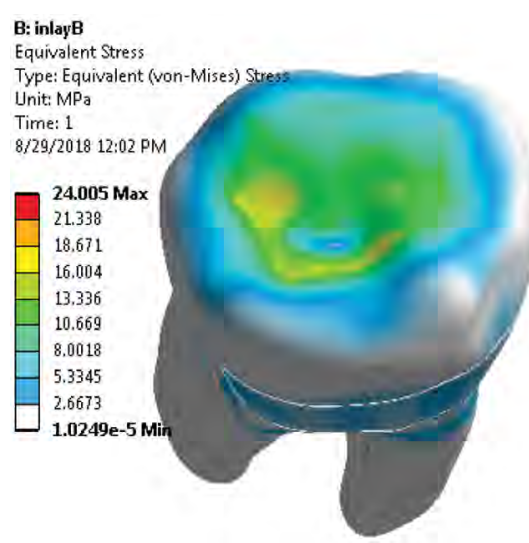

c) tensiuni de suprafață vedere caudală
B: inlay $\mathrm{B}$

Equivalent Stress

Type: Equivalent (van-Mises) Stres

Unit: $M P_{3}$

Time: 1

8/29/2018 11:55 AM

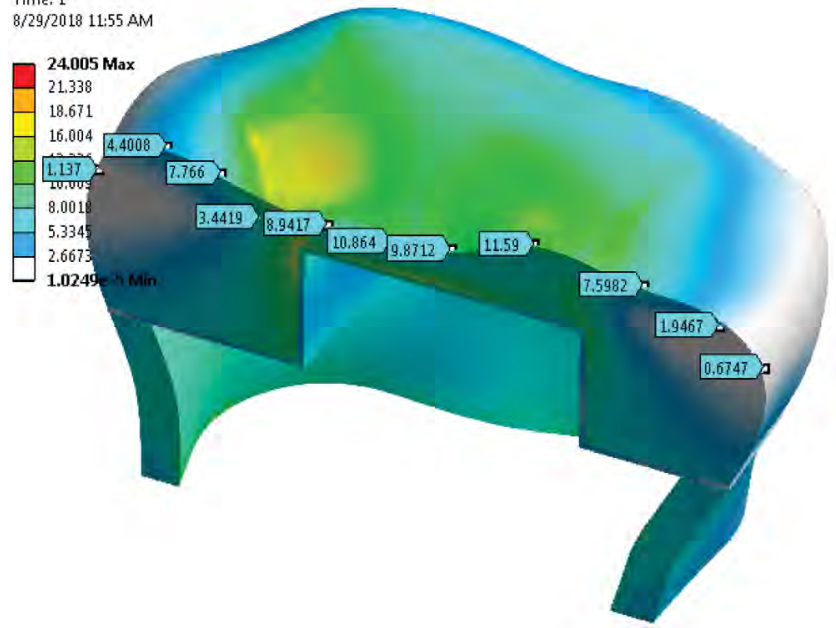

d) harta tensiunilor de suprafață

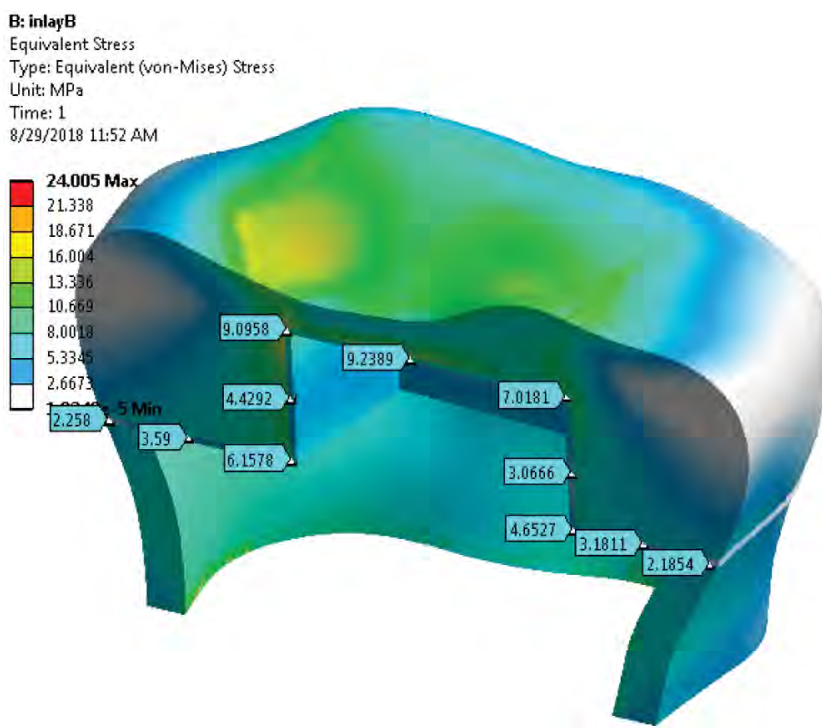

e) harta tensiunilor de interfață

FIGURA 8. Rezultatele simulării pentru solicitarea verticală, $230 \mathrm{~N}$ 


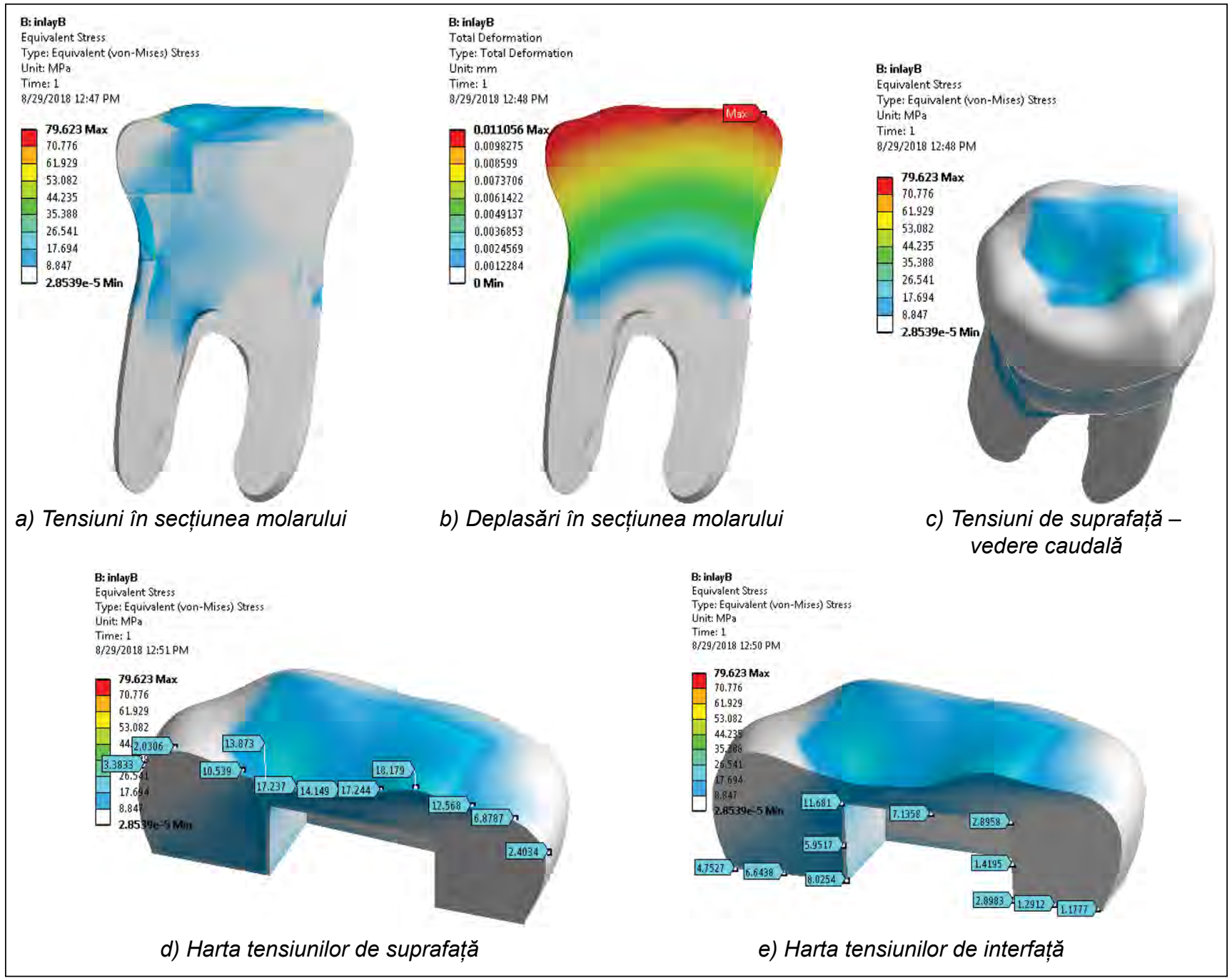

FIGURA 9. Rezultatele simulării pentru solicitarea oblică, 230 N

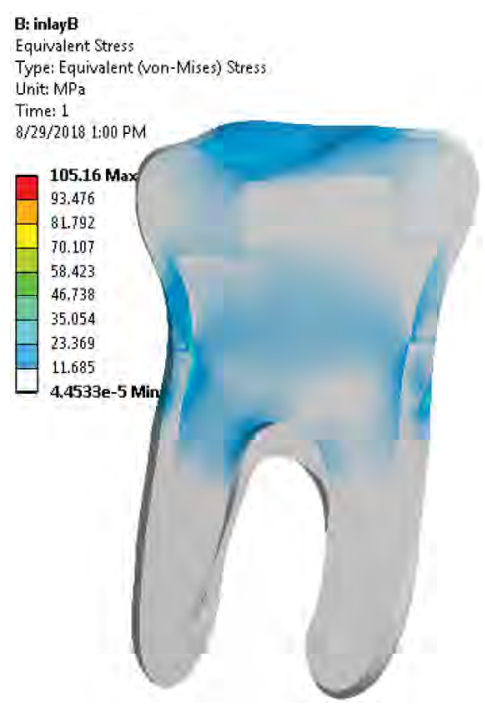

a) Tensiuni în secțiunea molarului

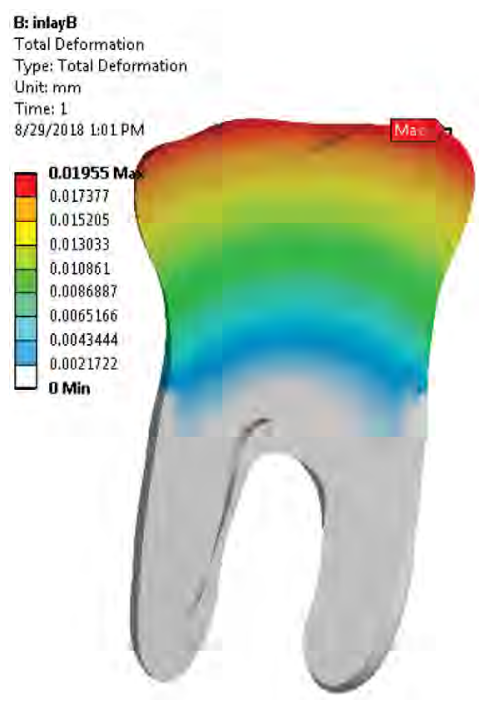

b) Deplasări în secțiunea molarului

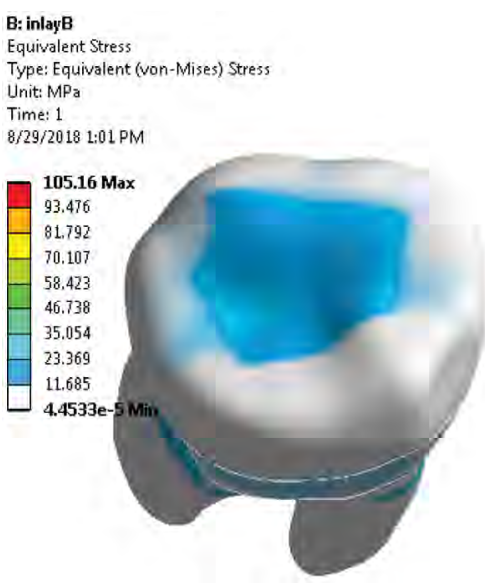

c) Tensiuni de suprafață vedere caudală 


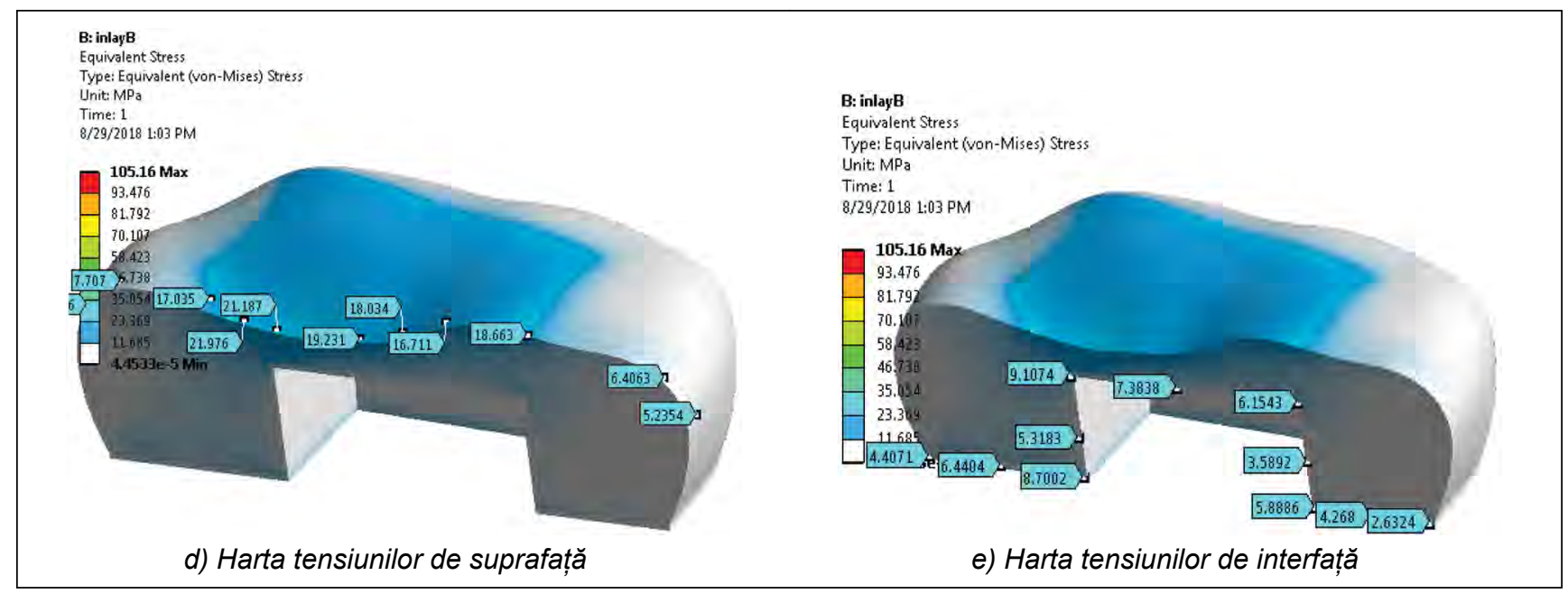

FIGURA 10. Rezultatele simulării pentru solicitarea orizontală, 230 N (continuare)

În tabelele 3 şi 4 se prezintă valorile tensiunilor din punctele de control considerate, împreună cu mediile şi deviaţiile standard calculate pe fiecare valoare de solicitare în parte.

TABELUL 3. Valorile de tensiune din suprafață

\begin{tabular}{|c|c|c|c|c|c|c|c|c|c|c|}
\hline \multirow{2}{*}{$\begin{array}{c}\text { Pct. } \\
\text { Ctrl. }\end{array}$} & $\mathbf{9 0}$ & $\mathbf{2 3 0}$ & $\mathbf{9 0}$ & $\mathbf{2 3 0}$ & $\mathbf{9 0}$ & $\mathbf{2 3 0}$ & $\begin{array}{c}\text { Media } \\
\text { (N) } \\
\text { mod=90 }\end{array}$ & $\begin{array}{c}\text { Std. (N) } \\
\text { mod=90 }\end{array}$ & $\begin{array}{c}\text { Media (N) } \\
\text { mod=230 }\end{array}$ & $\begin{array}{c}\text { Std. (N) } \\
\text { mod=230 }\end{array}$ \\
\hline 1 & 0,39 & 1,34 & 1,43 & 3,38 & 2,40 & 6,85 & 1,41 & 1,01 & 3,86 & 2,79 \\
\hline 2 & 1,64 & 4,40 & 1,13 & 2,03 & 3,01 & 7,70 & 1,93 & 0,97 & 4,71 & 2,85 \\
\hline 3 & 3,51 & 7,76 & 5,66 & 10,53 & 6,38 & 17,03 & 5,18 & 1,49 & 11,77 & 4,76 \\
\hline 4 & 5,92 & 3,44 & 6,17 & 13,87 & 8,05 & 21,97 & 6,71 & 1,16 & 13,09 & 9,29 \\
\hline 5 & 3,47 & 8,94 & 7,18 & 17,23 & 8,85 & 21,18 & 6,50 & 2,75 & 15,78 & 6,25 \\
\hline 6 & 3,99 & 10,84 & 6,03 & 14,14 & 7,55 & 19,23 & 5,86 & 1,79 & 14,74 & 4,23 \\
\hline 7 & 3,79 & 9,78 & 7,08 & 17,24 & 6,85 & 18,03 & 5,91 & 1,84 & 15,02 & 4,55 \\
\hline 8 & 4,90 & 11,59 & 7,29 & 18,17 & 6,62 & 16,71 & 6,27 & 1,23 & 15,49 & 3,46 \\
\hline 9 & 4,07 & 7,59 & 5,55 & 12,56 & 5,99 & 18,66 & 5,20 & 1,01 & 12,94 & 5,54 \\
\hline 10 & 1,34 & 1,94 & 2,68 & 6,87 & 3,13 & 6,40 & 2,38 & 0,93 & 5,07 & 2,72 \\
\hline 11 & 0,20 & 0,67 & 1,16 & 2,41 & 2,26 & 5,23 & 1,21 & 1,03 & 2,77 & 2,30 \\
\hline
\end{tabular}

TABELUL 4. Valorile de tensiune din interfață

\begin{tabular}{|c|c|c|c|c|c|c|c|c|c|c|}
\hline \multirow{2}{*}{$\begin{array}{l}\text { Pct. } \\
\text { Ctrl. }\end{array}$} & \multicolumn{6}{|c|}{ Valoare forță de încărcare (N) } & \multirow{2}{*}{$\begin{array}{c}\text { Media } \\
(\mathrm{N}) \\
\bmod =90\end{array}$} & \multirow{2}{*}{$\begin{array}{l}\text { Std. }(\mathrm{N}) \\
\bmod =90\end{array}$} & \multirow{2}{*}{$\begin{array}{c}\text { Media (N) } \\
\bmod =230\end{array}$} & \multirow{2}{*}{$\begin{array}{c}\text { Std. }(\mathrm{N}) \\
\bmod =230\end{array}$} \\
\hline & 90 & 230 & 90 & 230 & 90 & 230 & & & & \\
\hline 1 & 0,83 & 2,25 & 2,04 & 4,75 & 1,62 & 4,40 & 1,50 & 0,61 & 3,80 & 1,35 \\
\hline 2 & 1,44 & 3,59 & 2,82 & 6,64 & 2,53 & 6,44 & 2,26 & 0,73 & 5,56 & 1,71 \\
\hline 3 & 2,46 & 6,15 & 3,37 & 8,02 & 3,37 & 8,70 & 3,07 & 0,53 & 7,62 & 1,32 \\
\hline 4 & 1,74 & 4,42 & 2,48 & 5,95 & 2,12 & 5,31 & 2,11 & 0,37 & 5,23 & 0,77 \\
\hline 5 & 3,55 & 9,09 & 4,66 & 11,68 & 3,60 & 9,10 & 3,94 & 0,63 & 9,96 & 1,49 \\
\hline 6 & 3,61 & 9,23 & 3,20 & 7,13 & 2,92 & 7,38 & 3,24 & 0,35 & 7,91 & 1,15 \\
\hline 7 & 2,61 & 7,08 & 0,95 & 2,89 & 2,42 & 6,15 & 1,99 & 0,91 & 5,37 & 2,20 \\
\hline 8 & 1,27 & 3,06 & 0,54 & 1,41 & 1,40 & 3,58 & 1,07 & 0,46 & 2,68 & 1,13 \\
\hline 9 & 1,78 & 4,56 & 1,21 & 2,89 & 2,27 & 5,88 & 1,75 & 0,53 & 4,44 & 1,50 \\
\hline 10 & 1,31 & 3,18 & 0,62 & 1,29 & 1,64 & 4,26 & 1,19 & 0,52 & 2,91 & 1,50 \\
\hline 11 & 0,88 & 2,18 & 0,52 & 1,17 & 1,04 & 2,63 & 0,81 & 0,27 & 1,99 & 0,75 \\
\hline
\end{tabular}


Ambele tipuri de cimenturi prezintă şi de această dată valori de rezistenţă mai ridicate decât valorile de tensiune înregistrate atât la nivelul suprafeţei, cât şi la interfaţă. Acest lucru ne indică faptul că oricare dintre cele două valori de solicitare, aplicate după oricare dintre cele 3 direcţii, nu va produce

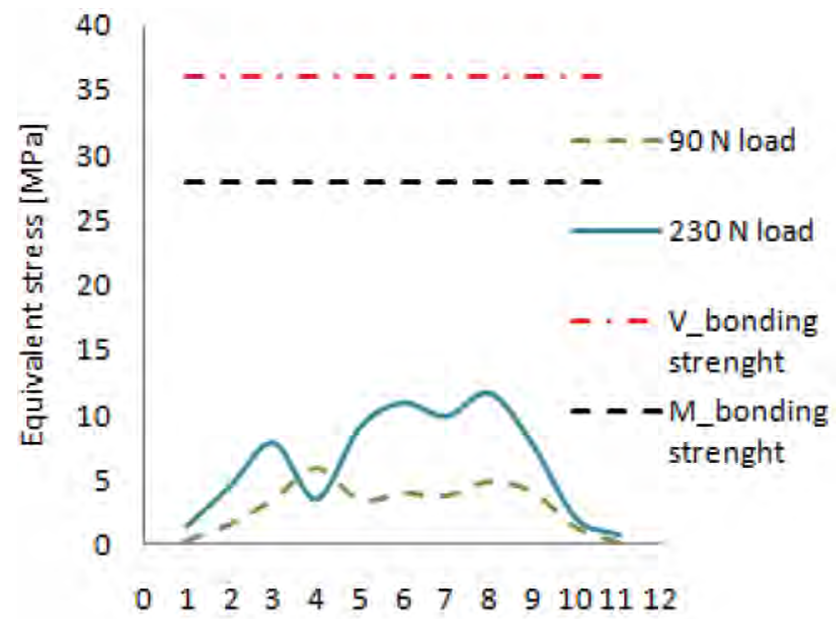

Node

a) Suprafață ruptura niciunuia dintre cele două tipuri de adeziv (fig. 11-13). Din punct de vedere calitativ, se poate observa simetria distribuţiei tensiunilor pe molar în cazul încărcărilor simetrice, respectiv nesimetria distribuţiei pentru încărcări oblice.

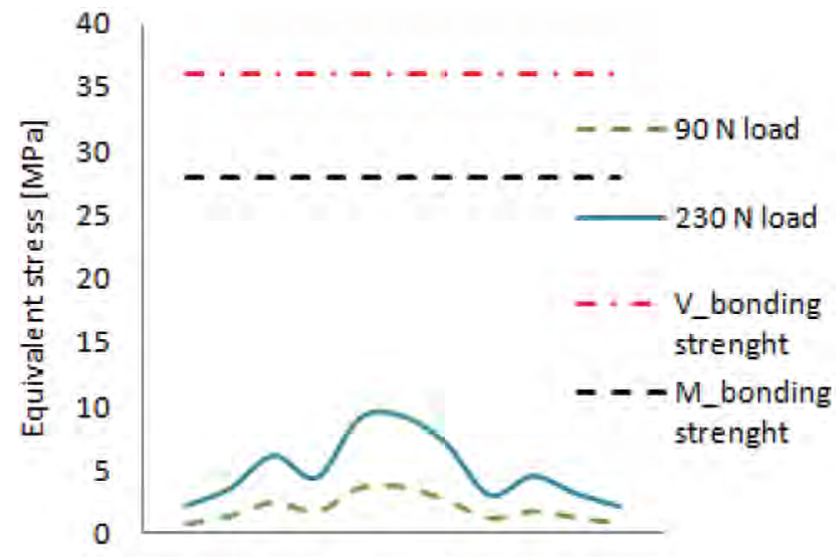

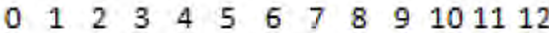

Node

b) Interfață

FIGURA 11. Variația tensiunilor din suprafață a) şi interfață b) pentru solicitarea verticală

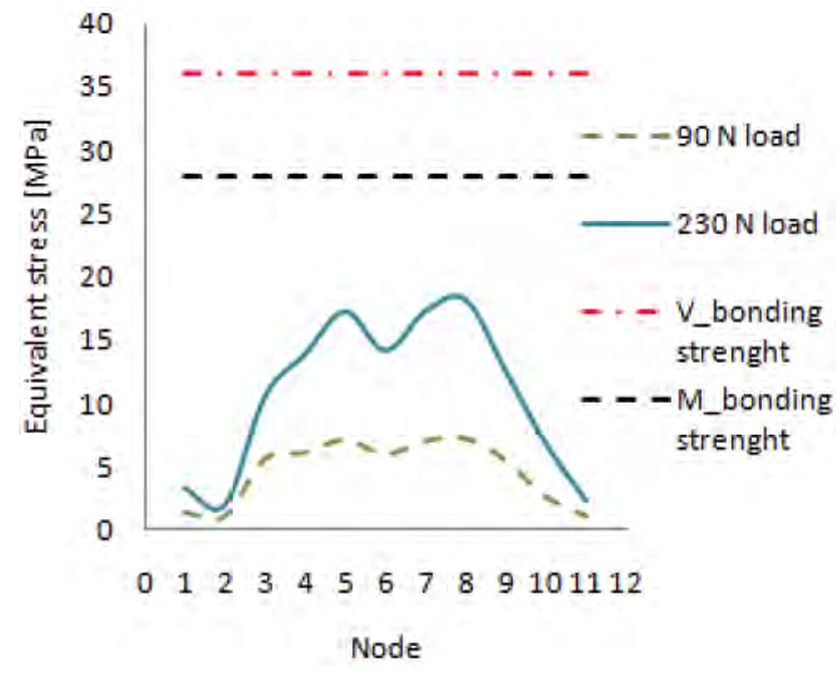

a) Suprafață

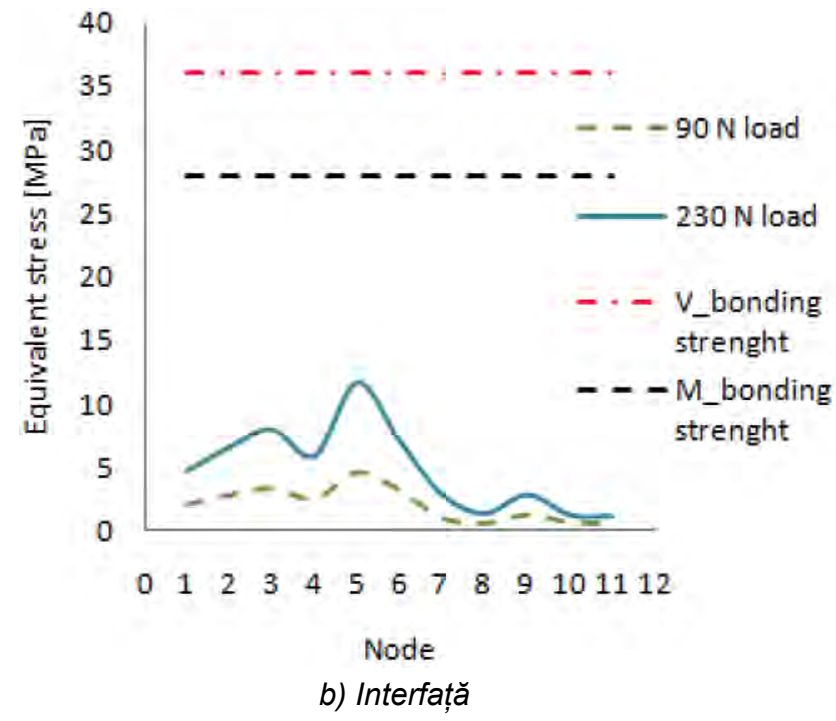

FIGURA 12. Variația tensiunilor din suprafață a) şi interfață b) pentru solicitarea oblică 


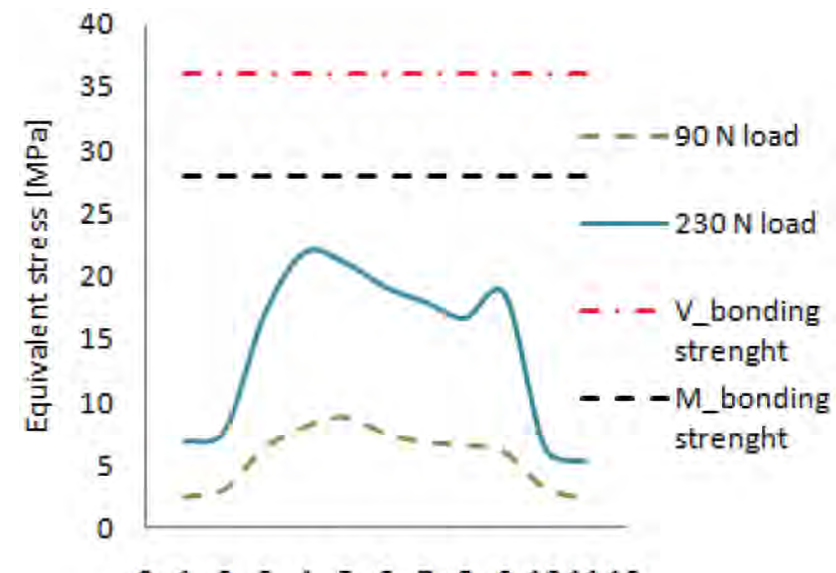

$\begin{array}{lllllllllll}0 & 1 & 2 & 3 & 4 & 5 & 6 & 7 & 8 & 9 & 101112\end{array}$

Node

a) Suprafață

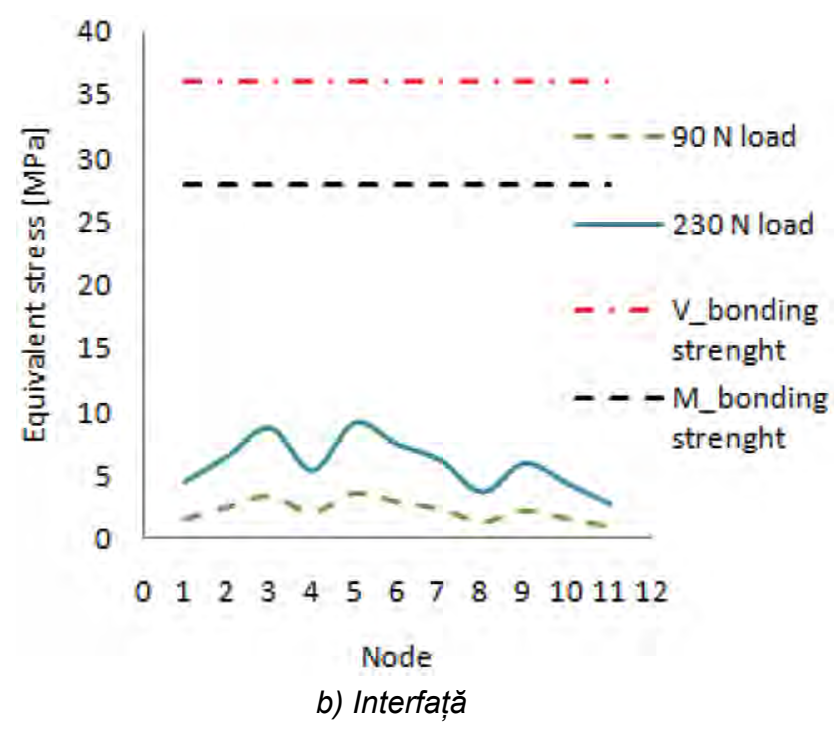

FIGURA 13. Variația tensiunilor din suprafață a) şi interfață b) pentru solicitarea orizontală

\section{Rezultatele modelului de inlay iC (ocluzo-proximal)}

Modelul de inlay iC reprezintă un model geometric nesimetric în raport cu axa longitudinală a molarului. În vederea aşezării pe dentină, acesta a fost realizat în două trepte geometrice, trepte care, din punct de vedere mecanic, se vor comporta ca zone concentratoare ale tensiunilor. Pentru preîntâmpinarea pe cât posibil a acestui lucru, s-au realizat raze de racordare ale elementelor geometrice.

Încărcarea s-a definit conform figurii prezentate la material şi metodă, cu punctul de aplicaţie de suprafaţa cea mai extremă a inlay-ului. Direcţiile de solicitare s-au păstrat la fel ca în cele două cazuri precedente.
În cazul încărcării verticale, tensiunile din materialul de cimentare sunt cele mai mari în zona cu grosimea de perete cea mai redusă, adică în zona laterală a molarului. Valorile de tensiune au un comportament complet nesimetric atât la suprafaţa, cât şi la interfaţa inlay-ului, din cauza nesimetriei geometrice.

Modul de transmitere al solicitărilor în acest caz se face cu precădere de la materialul de restaurare prin zona de smalţ spre zona de cement a dintelui, datorită modulelor de elasticitate mai ridicate ale acestor două materiale în comparaţie cu dentina.

Rezultatele simulărilor sub forma de hărţi de variaţie se prezintă în figurile 14-16. Secţiunea de eşantionare a tensiunilor s-a ales într-un plan per-

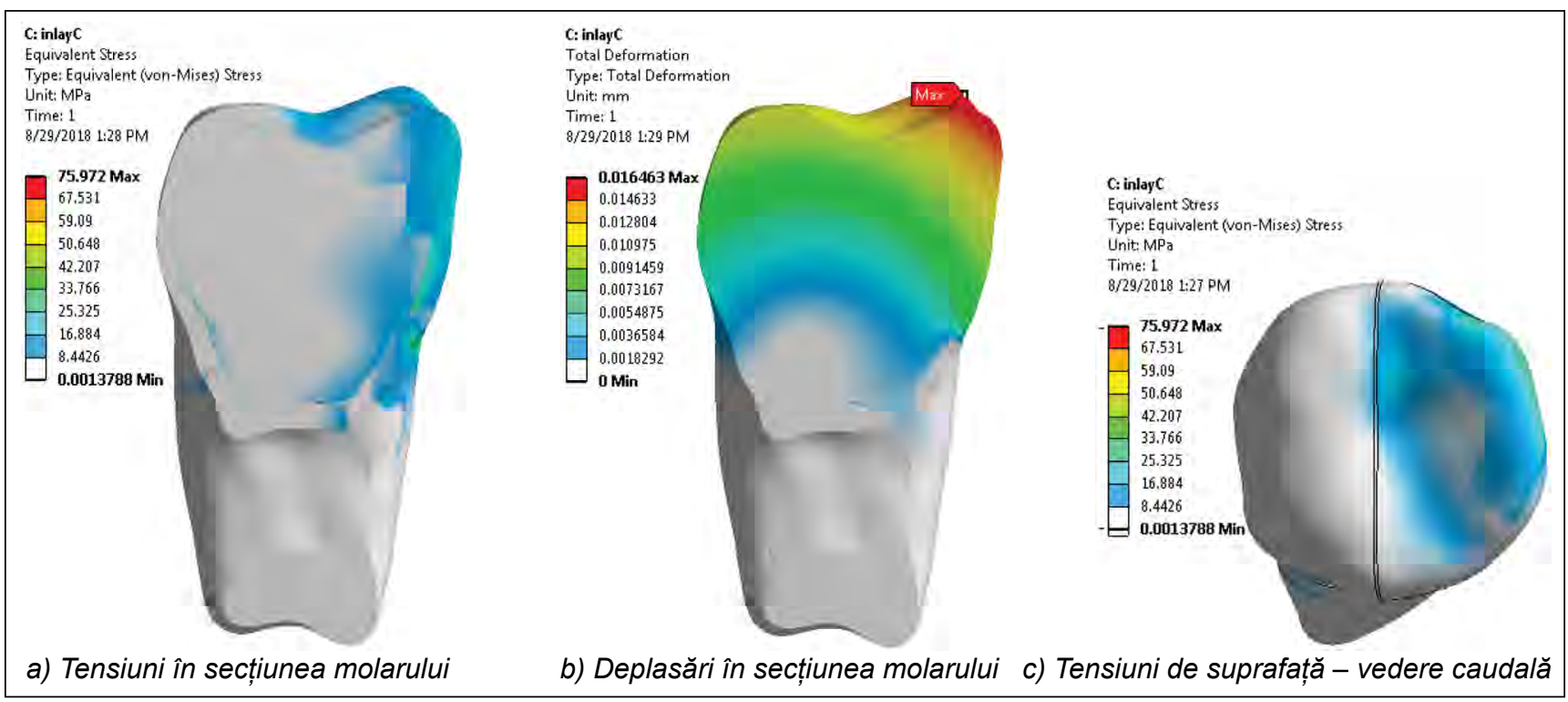

FIGURA 14. Rezultatele simulării pentru solicitarea verticală, $230 \mathrm{~N}$ 


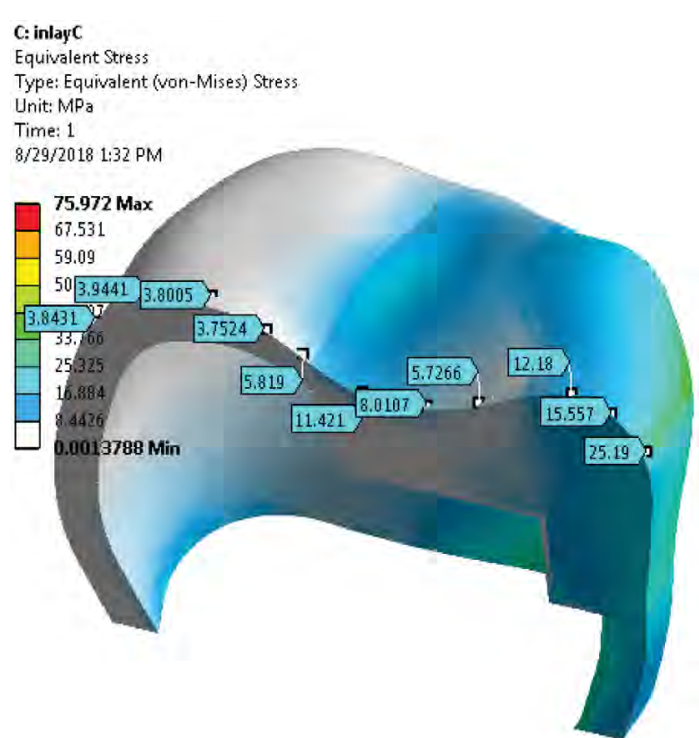

d) Harta tensiunilor de suprafață

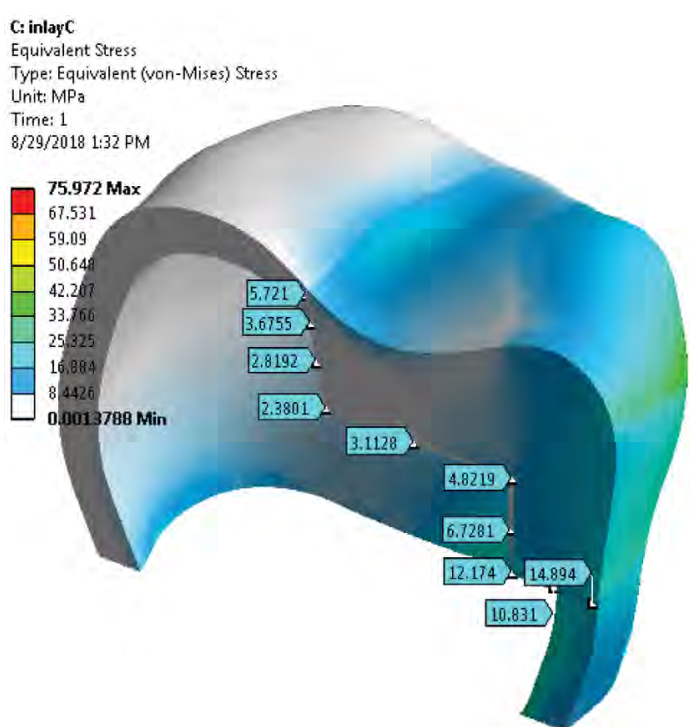

e) Harta tensiunilor de interfață

FIGURA 14. Rezultatele simulării pentru solicitarea verticală, 230 N (continuare)

pendicular pe direcţia inlay-ului, pentru a putea pune în evidenţă comportamentul mecanic de-a lungul celor două trepte ale acestuia.

Pe măsură ce solicitarea îşi schimbă orientarea de la una verticală spre orizontală, se observă o tensionare tot mai pronunţată a zonei interioare a inlay-ului, din cauza apariţiei tensiunilor normale în această zonă.

Acestui tip de inlay îi este specifică o modificare bruscă a tensiunilor la limitele de trecere de la un material la altul. Acest lucru poate fi observat în toate figurile, prin diferenţele de culoare de la albastru/galben spre gri (solicitare foarte redusă).

Din cauza apariţiei tensiunilor de forfecare, în cazul solicitării orizontale este depăşită valoarea rezistenţei mecanice a materialului de cimentare pentru solicitarea accidentală de $230 \mathrm{~N}$.

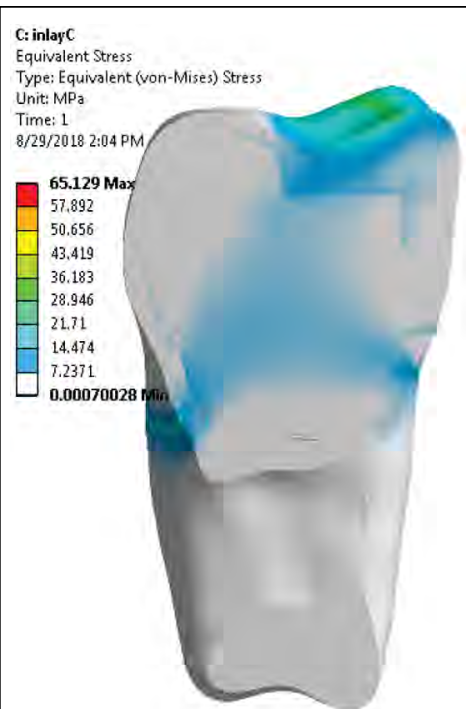

a) Tensiuni în secțiunea molarului

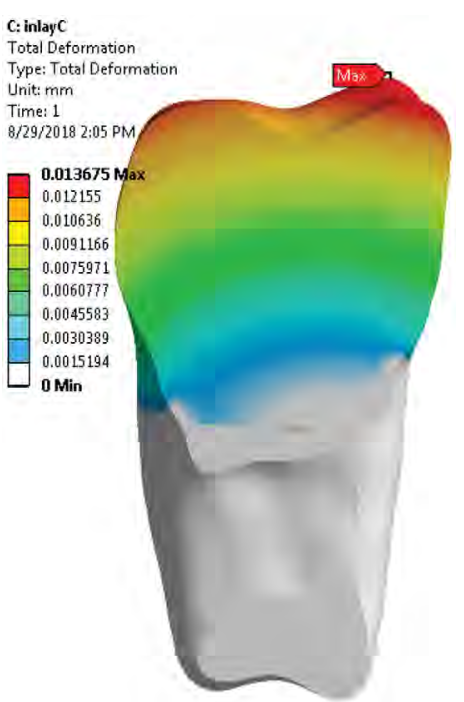

b) Deplasări în secțiunea molarului

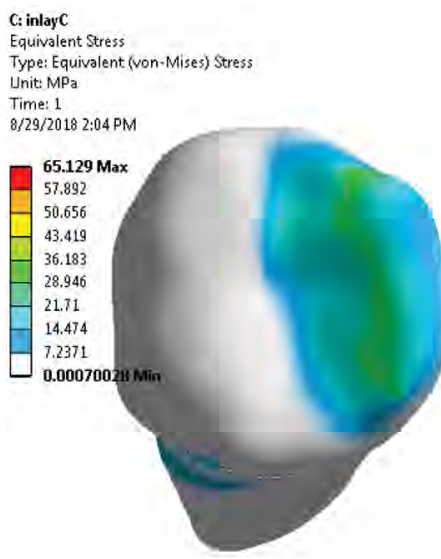

c) Tensiuni de suprafață vedere caudală

FIGURA 15. Rezultatele simulării pentru solicitarea oblică, $230 \mathrm{~N}$ 


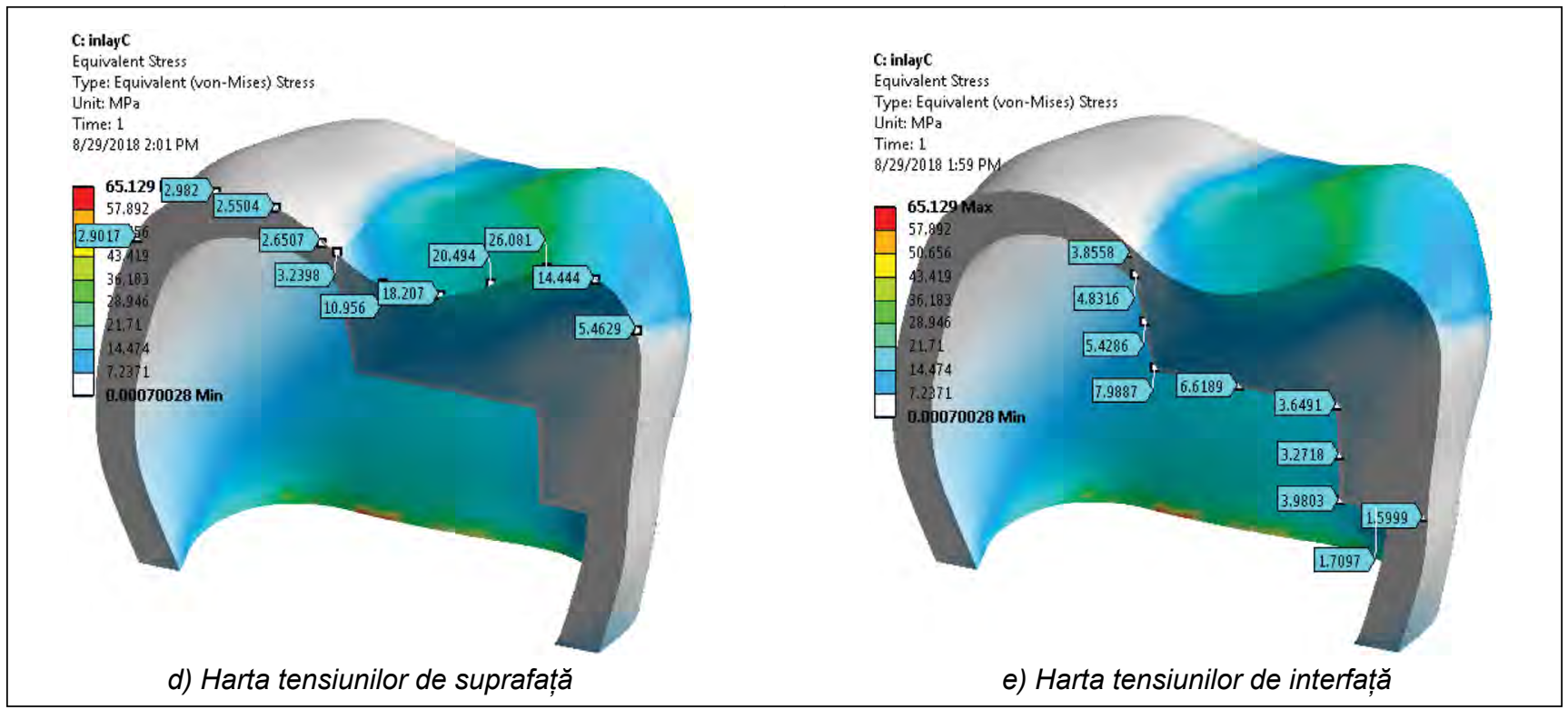

FIGURA 15. Rezultatele simulării pentru solicitarea oblică, 230 N (continuare)

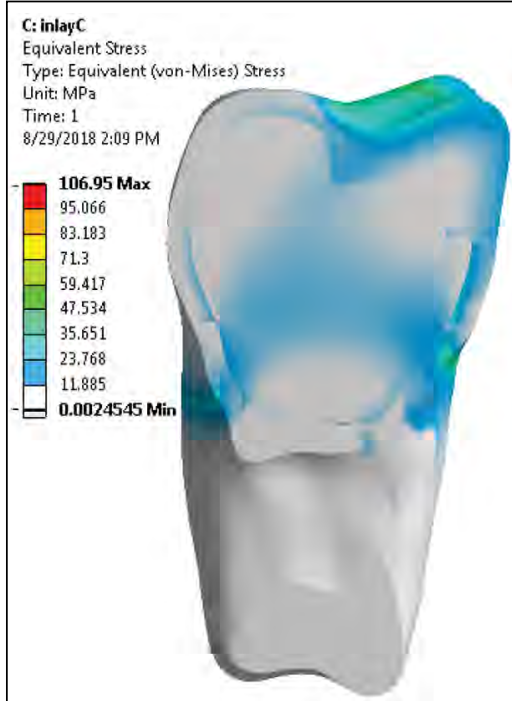

a) Tensiuni în secțiunea molarului

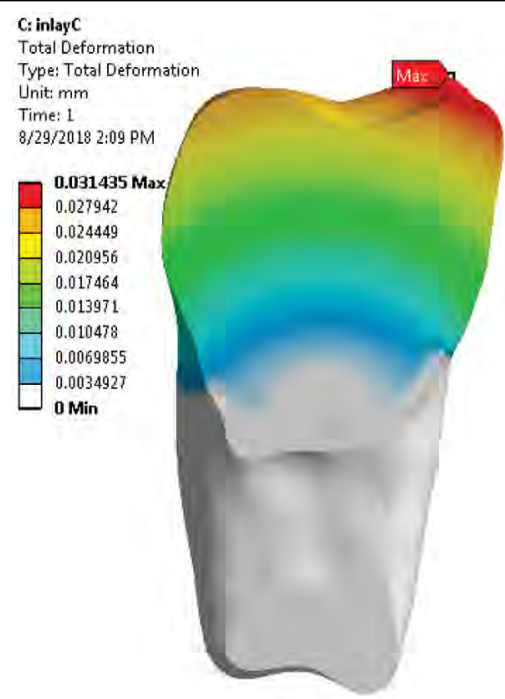

b) Deplasări în secțiunea molarului

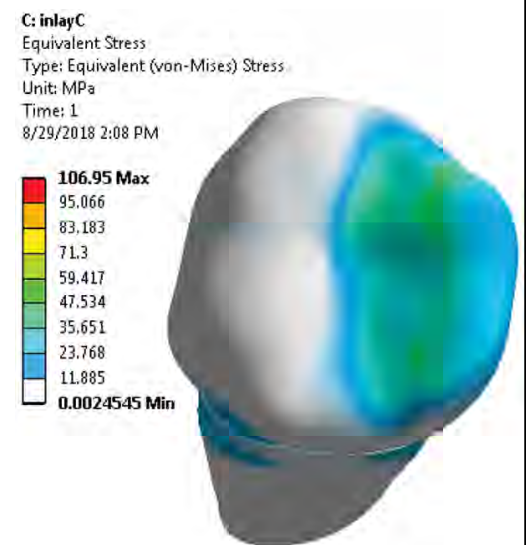

c) Tensiuni de suprafață - vedere caudală

C: inlayc

Equivalent Stress

Type: Equivalent (von-Mises) Stress

Unit: $\mathrm{MPa}$

Time: 1
8/29/2018 2:11 PM

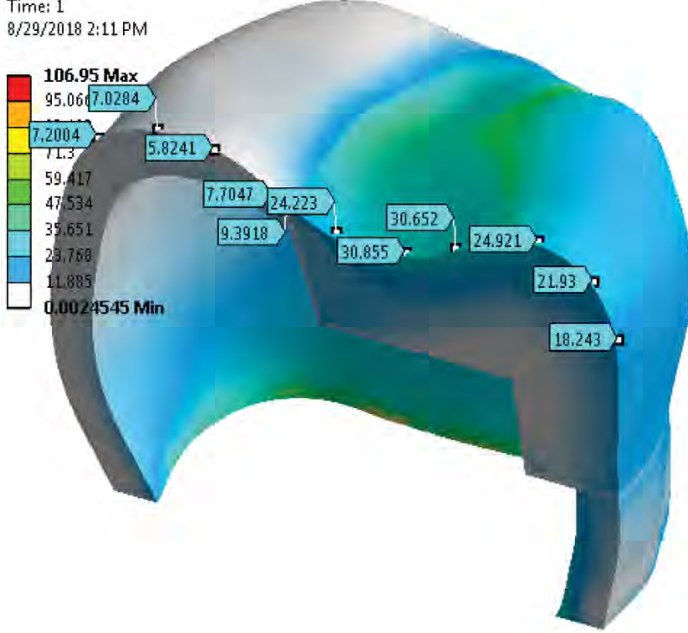

d) Harta tensiunilor de suprafață

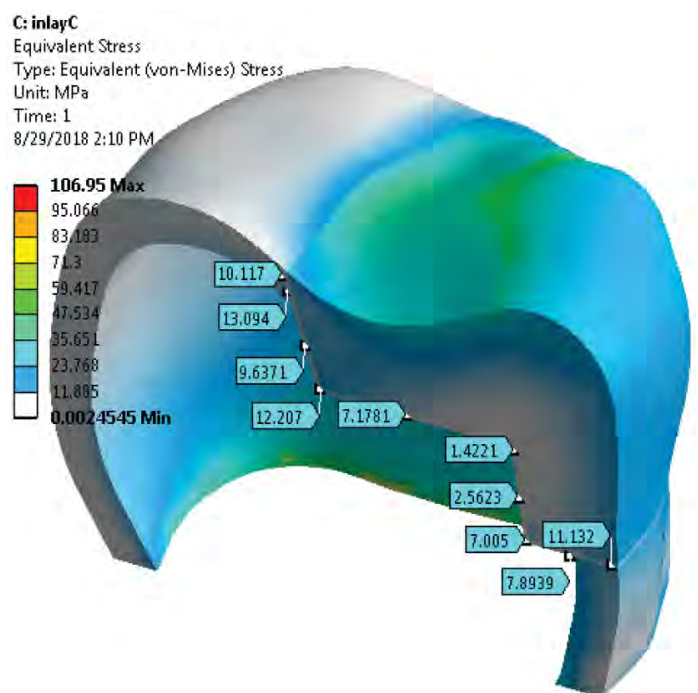

e) Harta tensiunilor de interfață 
În tabelele 5 şi 6 se prezintă valorile tensiunilor din punctele de cotrol considerate, împreună cu mediile şi deviaţiile standard calculate pe fiecare valoare de solicitare în parte.

Graficele din figurile 17-19 ne prezintă în mod explicit caracterul nesimetric al solicitării, pe de-o parte, iar, pe de altă parte, zonele critice ale modelului.

$\mathrm{Cu}$ o singură excepţie (tensiunile din suprafaţa molarului la solicitarea orizontală), se constată că, indiferent de tipul de material adeziv utilizat, valorile de rezistenţă ale acestora sunt mai ridicate decât valorile de tensiune înregistrate. Acest lucru ne indică faptul că oricare dintre cele două valori de solicitare, aplicate după oricare dintre cele 3 direcţii, nu va produce ruptura niciunuia dintre cele două tipuri de ciment.

TABELUL 5. Valorile de tensiune din suprafață

\begin{tabular}{|c|c|c|c|c|c|c|c|c|c|c|}
\hline \multirow{2}{*}{$\begin{array}{c}\text { Pct. } \\
\text { Ctrl. }\end{array}$} & $\mathbf{9 0}$ & $\mathbf{2 3 0}$ & $\mathbf{9 0}$ & $\mathbf{2 3 0}$ & $\mathbf{9 0}$ & $\mathbf{2 3 0}$ & $\begin{array}{c}\text { Media } \\
\text { (N) } \\
\text { mod=90 }\end{array}$ & $\begin{array}{c}\text { Std. (N) } \\
\text { mod=90 }\end{array}$ & $\begin{array}{c}\text { Media (N) } \\
\text { mod=230 }\end{array}$ & $\begin{array}{c}\text { Std. (N) } \\
\text { mod=230 }\end{array}$ \\
\hline 1 & 1,56 & 4,03 & 0,84 & 2,90 & 2,75 & 7,20 & 1,72 & 0,96 & 4,71 & 2,23 \\
\hline 2 & 1,51 & 3,90 & 0,75 & 2,98 & 2,80 & 7,02 & 1,69 & 1,04 & 4,63 & 2,12 \\
\hline 3 & 1,54 & 3,85 & 0,69 & 2,55 & 2,47 & 5,82 & 1,57 & 0,89 & 4,07 & 1,65 \\
\hline 4 & 1,70 & 4,09 & 0,70 & 2,65 & 2,64 & 7,70 & 1,68 & 0,97 & 4,81 & 2,60 \\
\hline 5 & 2,20 & 6,27 & 0,64 & 3,23 & 3,63 & 9,39 & 2,16 & 1,50 & 6,30 & 3,08 \\
\hline 6 & 4,44 & 11,18 & 2,07 & 10,95 & 9,91 & 24,22 & 5,47 & 4,02 & 15,45 & 7,60 \\
\hline 7 & 2,75 & 9,15 & 4,07 & 18,20 & 12,06 & 30,85 & 6,29 & 5,04 & 19,40 & 10,90 \\
\hline 8 & 2,21 & 5,80 & 5,68 & 20,49 & 13,02 & 30,65 & 6,97 & 5,52 & 18,98 & 12,49 \\
\hline 9 & 4,48 & 10,09 & 11,01 & 26,08 & 9,80 & 24,92 & 8,43 & 3,47 & 20,36 & 8,92 \\
\hline 10 & 5,63 & 14,37 & 4,79 & 14,44 & 8,64 & 21,93 & 6,35 & 2,02 & 16,91 & 4,34 \\
\hline 11 & 10,4 & 26,90 & 3,48 & 5,46 & 7,25 & 18,24 & 7,07 & 3,50 & 16,87 & 10,79 \\
\hline
\end{tabular}

TABELUL 6. Valorile de tensiune din interfață

\begin{tabular}{|c|c|c|c|c|c|c|c|c|c|c|}
\hline \multirow{2}{*}{$\begin{array}{c}\text { Pct. } \\
\text { Ctrl. }\end{array}$} & $\mathbf{9 0}$ & $\mathbf{2 3 0}$ & $\mathbf{9 0}$ & $\mathbf{2 3 0}$ & $\mathbf{9 0}$ & $\mathbf{2 3 0}$ & $\begin{array}{c}\text { Media } \\
\text { (N) } \\
\text { mod=90 }\end{array}$ & $\begin{array}{c}\text { Std. (N) } \\
\text { mod=90 }\end{array}$ & $\begin{array}{c}\text { Media (N) } \\
\text { mod=230 }\end{array}$ & $\begin{array}{c}\text { Std. (N) } \\
\text { mod=230 }\end{array}$ \\
\hline 1 & 2,50 & 5,72 & 1,29 & 3,85 & 4,14 & 10,11 & 2,64 & 1,43 & 6,56 & 3,21 \\
\hline 2 & 1,51 & 3,67 & 1,23 & 4,83 & 3,98 & 13,09 & 2,24 & 1,51 & 7,20 & 5,14 \\
\hline 3 & 1,07 & 2,81 & 1,56 & 5,42 & 3,75 & 9,63 & 2,13 & 1,43 & 5,95 & 3,44 \\
\hline 4 & 0,94 & 2,31 & 2,46 & 7,98 & 4,79 & 12,20 & 2,73 & 1,94 & 7,50 & 4,96 \\
\hline 5 & 1,26 & 3,11 & 2,37 & 6,61 & 3,05 & 7,17 & 2,23 & 0,90 & 5,63 & 2,20 \\
\hline 6 & 1,99 & 4,28 & 1,58 & 3,64 & 0,54 & 1,42 & 1,37 & 0,75 & 3,11 & 1,50 \\
\hline 7 & 2,57 & 6,72 & 1,63 & 3,27 & 0,97 & 2,56 & 1,72 & 0,80 & 4,18 & 2,23 \\
\hline 8 & 4,75 & 12,17 & 2,30 & 3,98 & 2,67 & 7,00 & 3,24 & 1,32 & 7,72 & 4,14 \\
\hline 9 & 4,40 & 10,83 & 1,54 & 1,70 & 3,02 & 7,89 & 2,99 & 1,43 & 6,81 & 4,66 \\
\hline 10 & 5,86 & 14,89 & 1,83 & 1,59 & 4,35 & 11,13 & 4,01 & 2,04 & 9,20 & 6,86 \\
\hline
\end{tabular}




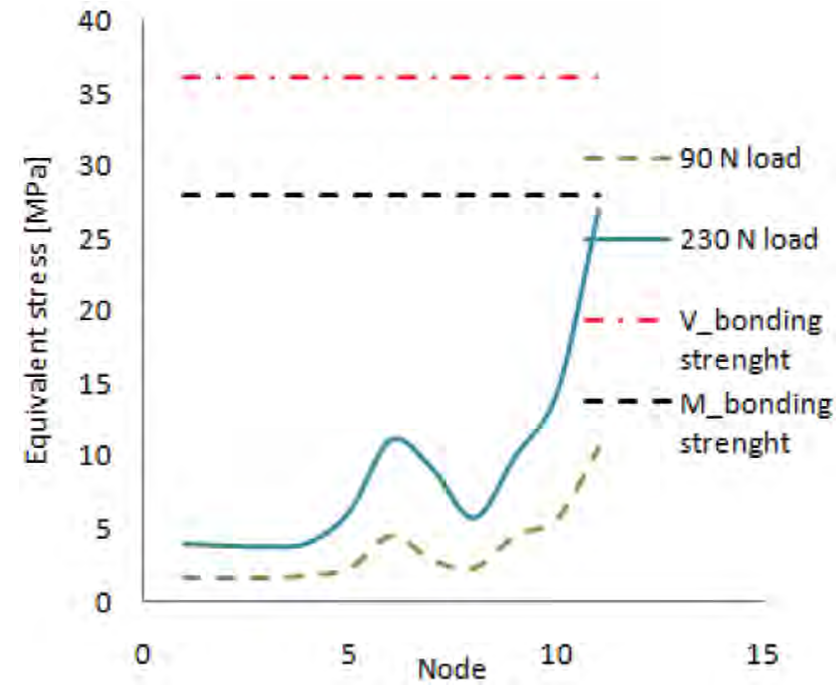

a) Suprafața

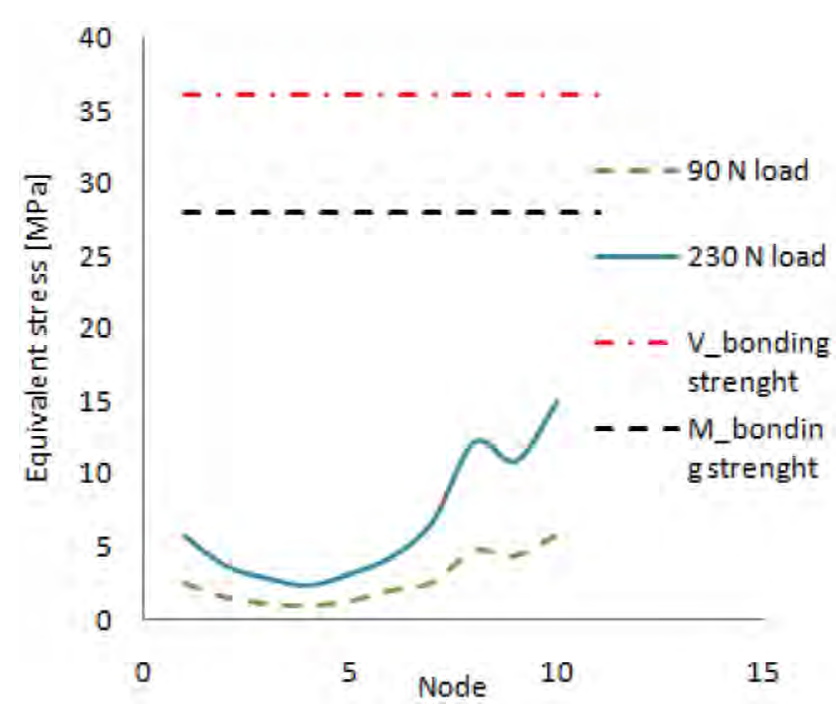

b) Interfața

FIGURA 17. Variația tensiunilor din suprafață a) şi interfață b) pentru solicitarea verticală

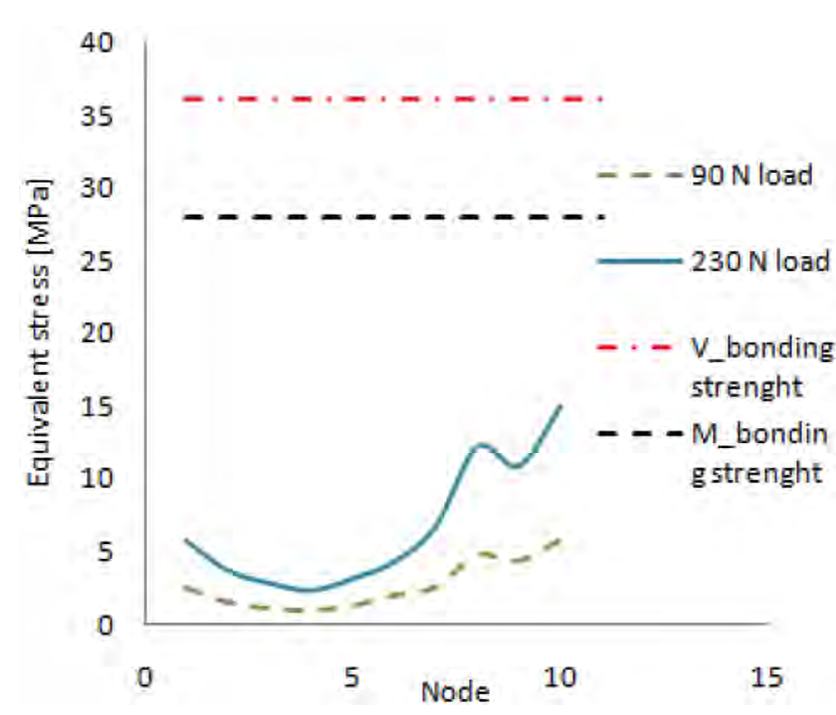

a) Suprafața

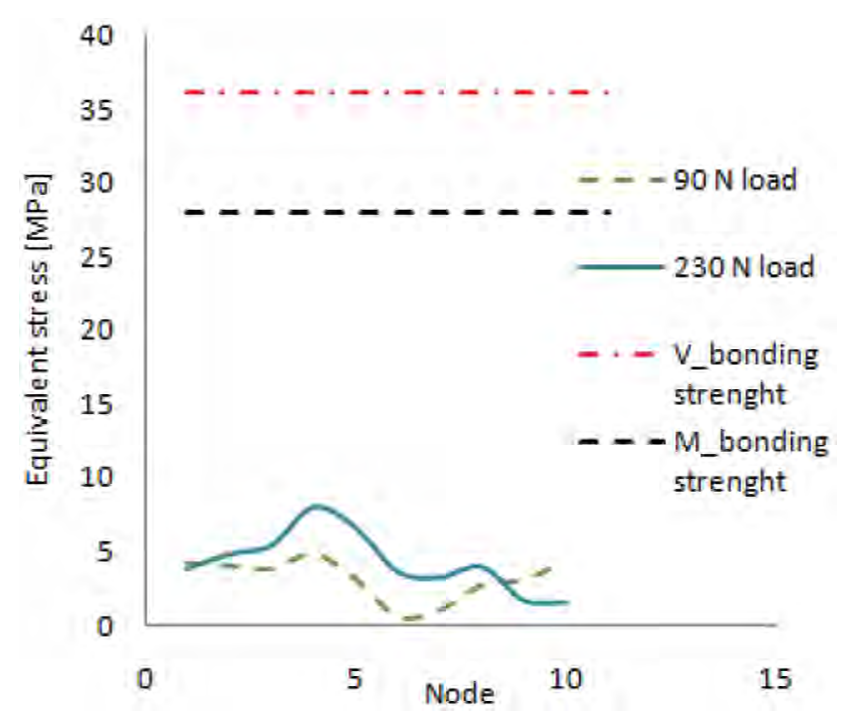

b) Interfața

FIGURA 18. Variația tensiunilor din suprafață a) şi interfață b) pentru solicitarea oblică

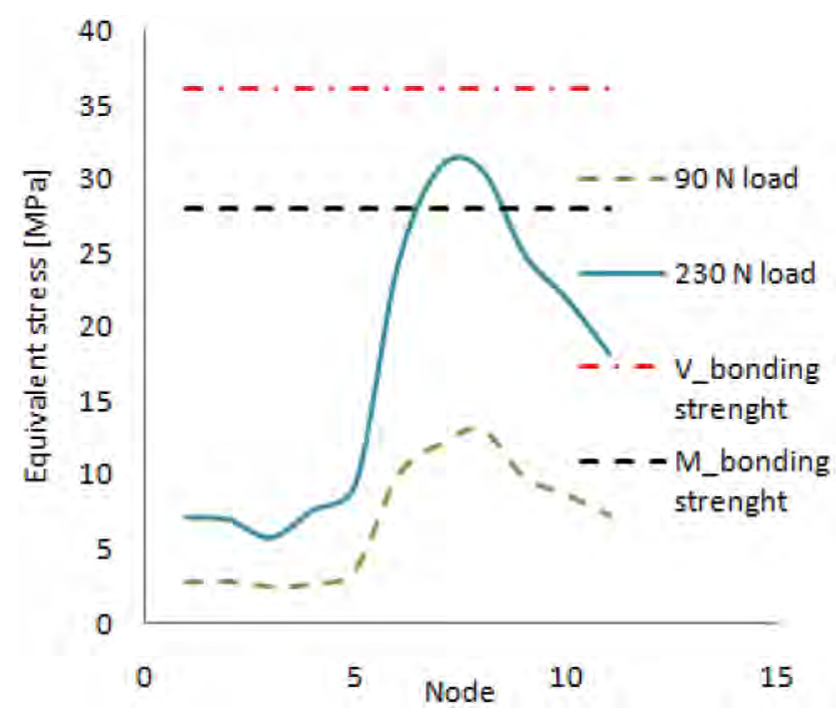

a) Suprafața

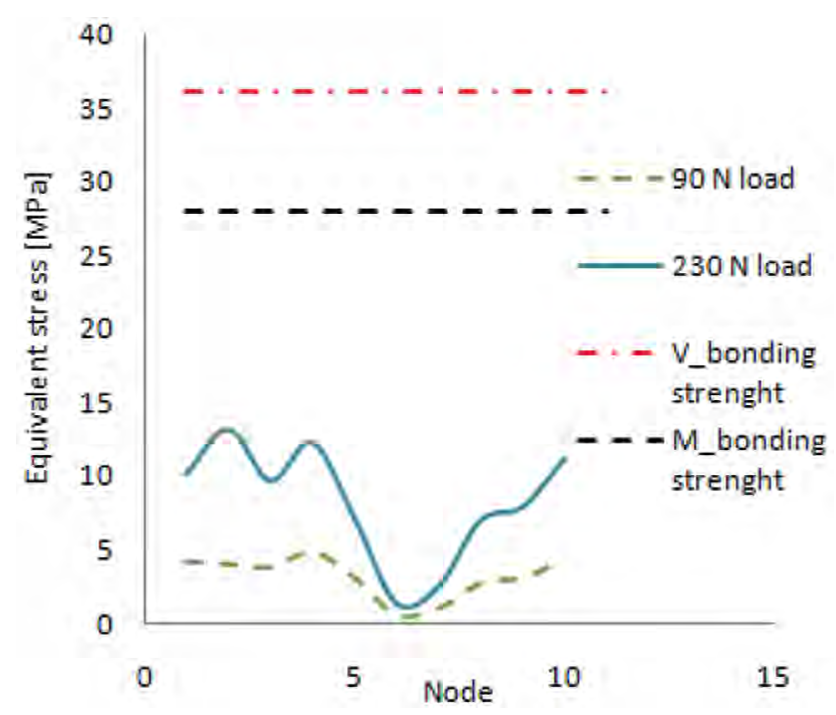

b) Interfața

FIGURA 19. Variația tensiunilor din suprafață a) şi interfață b) pentru solicitarea orizontală 


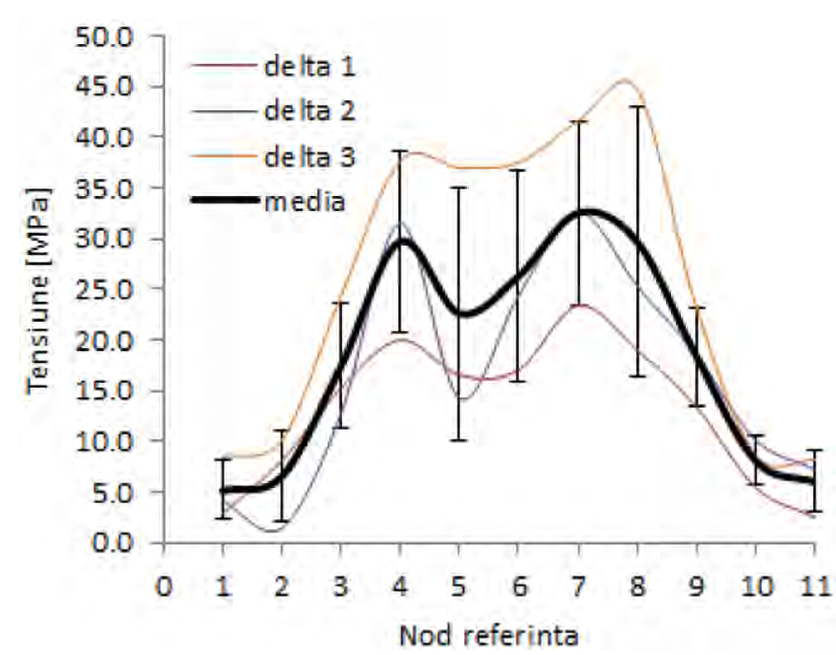

FIGURA 20A. Tensiunile din suprafață în cazul inlay-ului iA, pentru cele 3 direcții de solicitare (delta 1 - vertical, delta 2 - oblic, delta 3 - orizontal) şi modulul forței de $230 \mathrm{~N}$

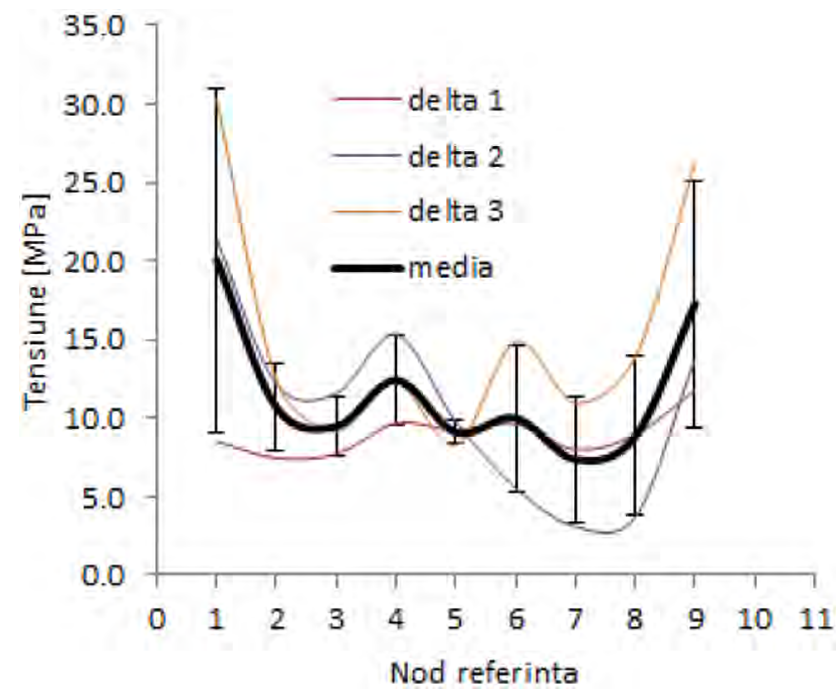

FIGURA 20B. Tensiunile din interfață în cazul inlay-ului iA, pentru cele 3 direcții de solicitare (delta 1 - vertical, delta 2 - oblic, delta 3 - orizontal) şi modulul forței de $230 \mathrm{~N}$

\section{CONCLUZII}

Studiul de faţă a fost realizat în vederea evaluării rezistenţei mecanice la adeziune cu două tipuri de cimenturi autoadezive estetice utilizate pentru a fixa trei geometrii de inlay-uri integral ceramice.

Variolink II are proprietăţi de adeziune superioare cimentului Maxcem, motiv pentru care -indiferent de configuraţia geometrică, direcţia forţei de aplicare şi modulul utilizate în simulare - adeziunea cu cimentul Variolink are rezistenţa mecanică mai ridicată. Din punctul de vedere al modului de distribuție al tensiunilor pe oricare dintre cele trei tipuri de inlay-uri, în cazul în care forţa are o direcţie simetrică faţă de inlay, tensiunile se distribuie uniform, circumferenţial, pornind de la valori mai mari în centrul suprafeței exterioare şi ajungând la valori reduse în zonele marginale (fig. 20A-20B).

Tensiunile la interfaţa ciment-ţesut dentar sunt mai reduse decât tensiunile de suprafaţă, datorită modulului de elasticitate mai redus al materialului de cimentare comparativ cu smalţul dentar, respectiv materialul de restaurare, indiferent de tipul cimentului autoadeziv. Inlay-ul cu geometrie nesimetrică $(i C)$ se caracterizează prin salturi bruşte de tensiune la interfeţele de trecere de la un material la altul. Acest caz este cel mai susceptibil de a genera tensiuni care să depăşească limita de rezistenţă la adeziune a cimenturilor.

Inlay-urile de dimensiuni geometrice mari pot prelua şi transmite mai bine tensiunile de la suprafaţa dintelui, prin intermediul cimentului adeziv la structura dentară.

\section{Mențiune}

Toţi autorii au contribuţie egală în realizarea acestui articol.

\section{BIBLIOGRAFIE}

1. Oh WS, Shen C. Effect of surface topography on the bond strength of a composite to three different types of ceramic. J Prosthet Dent. 2003 Sep;90(3):241-6.

2. DA Pîrvu, BM Gălbinaşu, I Pătraşcu, CF Pârvu, D Niţoi, Evaluarea interfeţei ciment autoadeziv-mase ceramice prin teste de forfecare. Revista Română de Materiale, 2012 42(2), pp. 193-203.

3. Pisani-Proenca J, Erhardt MC, Valandro LF, Gutierrez-Aceves G, Bolanos-Carmona MV, Del Castillo-Salmeron R, Bottino MA. Influence of ceramic surface conditioning and resin cements on microtensile bond strength to a glass ceramic. J Prosthet Dent. 2006 Dec;96(6):412-7.

4. REPORT no. 22/July 2016, Research and Development Ivoclar Vivadent AG, 9494 Schaan / Liechtenstein.

5. Kerr endodontics, on https://www.kerrdental.com/en-eu/cataloguesdownload.

6. Study conducted by Brown W., Bishop J., Park A., Fox L., Giordano E., Kugel G., Perry R. (2015). Bond strength of several self-adhesive cements to enamel and dentin.

7. 3M ESPE Competitive product Comparison, on.

8. http://multimedia.3m.com/mws/media/3216750/relyx-unicemmaxcem-competitive-comparison.pdf.

9. Sarr M, Leye-Benoist F, Aidara AW, Faye B, Bane K and Touré B. Characterization of the Resin Luting Materials: Percentage, 
Morphology and Mechanical Properties. Journal of Dentistry and Oral Care Medicine, Volume 2 | Issue 3, 2016.

10. ESTECEM Plus, Technical Report Ver.1.0 (2017.07.21), Tokuyama Dental.

11. T Furuichi, T Takamizawa, A Tsujimoto, M Miyazaki, WW Barkmeier, MA Latta. Mechanical Properties and Sliding-impact Wear
Resistance of Self-adhesive Resin Cements. Operative Dentistry, 2016, 41-3.

12. Flavia Zardo Trindade, Luiz Felipe Valandro, Niek de Jager, Marco Antonio Bottino, Cornelis Johannes Kleverlaan, Elastic Properties of Lithium Disilicate Versus Feldspathic Inlays: Effect on the Bonding by 3D Finite Element Analysis. Journal of Prosthodontics 00 (2016) 1-7. 